\title{
DEONTOLOGY, GOVERNMENTAL ACTION, AND THE DISTRIBUTIVE EXEMPTION: HOW THE TROLLEY PROBLEM SHAPES THE RELATIONSHIP BETWEEN RIGHTS AND POLICY
}

\author{
TIM STELzIG $†$
}

In proportion to the importance of the ... law ought also to be the care and attention of the legislature in properly forming and enforcing it. It should be founded upon principles that are permanent, uniform, and universal; and always conformable to the dictates of truth and justice, the feelings of humanity, and the indelible rights of mankind:

though it sometimes (provided there be no transgression of these eternal boundaries) may be modified, narrowed, or enlarged, according to the local or occasional necessities of the state which it is meant to govern.

-Blackstone

\section{INTRODUCTION}

Blackstone identifies a curious tension resting at the juncture of law and morality. As Blackstone notes, rights are "indelible." Where a right exists, morality prohibits its violation. This prohibition extends even-and perhaps especially-to situations in which greater good can be accomplished by violating the right. ${ }^{2}$ Rights act as

† B.A. 1990, West Virginia University; M.A. 1995, University of Illinois at Chicago; J.D. Candidate 1998, University of Pennsylvania. I would like to thank Professors Matthew Adler and Michael Moore, both of the University of Pennsylvania, for their contribution, largely unbeknownst to them, to the content of this piece. Both have shaped my thoughts significantly. Thanks also to Professor David Copp of the University of California, Davis, for comments on an early draft of this Comment. Lastly, I would like to thank the members of the Law Review for their editing.

' 4 WILIIAM BLACKSTONE, COMMENTARIES *2.

${ }^{2}$ Why this prohibition should ever be binding is something of an intellectual puzzle. See SAMUEL SCHEFfler, The REJECTION OF CONSEQUENTIALISM 80-114 (1982) (defending agent-centered restrictions on the grounds that they give sufficient attention to the personal point of view). If good really is good, rationality seemingly should require that even more good would be better. Nevertheless, it is morally impermissible to punch one person, even if doing so will distract Bob and prevent him from punching two people. 
"trumps," "side-constraints," or "shields" against the intrusive designs of the utility-maximizing consequentialist, ${ }^{6}$ insulating each person from being sacrificed for the public good. For example, torturing an innocent child is morally impermissible not because it fails to produce the greatest good, but because doing so would violate the child's rights. ${ }^{7}$ Nothing more need be said. ${ }^{8}$

Yet, as Blackstone also realizes, the "local or occasional necessities of the state" sometimes demand that rights be "modified, narrowed, or enlarged." Bluntly put, sometimes the public good wins out.

${ }^{3}$ See RONALD DWORKIN, TAKING RIGHTS SERIOUSLY 90-100, 190-97 (1978) (arguing that rights, properly understood, cannot be subordinated to the public good).

${ }^{4}$ See ROBERT NOZICK, ANARCHY, STATE, AND UTOPIA 26-53 (1974) (proposing a model of morality in which rights are "side constraints" on behavior, rather than part of the end state sought).

${ }^{5}$ See Frederick Schauer, A Comment on the Structure of Rights, 27 GA. L. REV. 415, 415, 429 (1993) (rejecting the conception of rights as absolute "trumps" or "side constraints," and instead reconceptualizing them as "shields," which offer protection from, but are not impervious to, government intrusion).

${ }^{6}$ Consequentialism is the genus of which utilitarianism is a species. Utilitarianism requires maximizing happiness. See JOHN STUART MILL, UTILITARIANISM 10 (Oskar Piest ed., Bobbs-Merrill Co. 1957) (1861) (stating that utilitarianism, which "accepts as the foundation of morals 'utility' or the 'greatest happiness principle' holds that actions are right in proportion as they tend to promote happiness; wrong as they tend to produce the reverse of happiness"). Consequentialism aims at promoting good consequences, however defined. Simply stated, (act-)consequentialism holds that the morally right act is that act which maximizes good consequences. Because the utilitarian takes happiness to be an intrinsically good state of affairs and seeks its maximization, the utilitarian is a consequentialist. See generally CONSEQUENTIALISM AND ITS CRITICs (Samuel Scheffler ed., 1988) (providing an introduction to the principles of consequentialism); J.J.C. SMART \& BERNARD WILLIAMS, UTILITARIANISM: FOR AND AGAINST (1973) (containing Smart's relatively short introduction to, and defense of, act-utilitarianism, to which Williams powerfully replies).

${ }^{7}$ As theorist Judith Jarvis Thomson points out, apologies are in order for the use of such examples:

Overheated examples in ethics are tiresome (one feels one's lapels are being clutched), and I apologize for this one. Still, if what is wanted is places where morality meshes with the world, then melodrama is useful: it supplies places where facts mesh directly with strong moral judgments to the effect that a person ought or ought not do a thing.

JUDITH JARVS THOMSON, THE REALM OF RIGHTS 18 (1990).

${ }^{8}$ Moreover, the very act of saying more suggests a lack of moral awareness. Attempting to account for the wrongness of torture by arguing that torturing innocent people cannot maximize the public good is morally misguided. Where a right exists, the consequences that might follow are generally irrelevant for purposes of morally evaluating the action.

${ }^{9} 4$ BLACKSTONE, supra note 1 , at $* 2$. As quoted, Blackstone is not selfcontradictory, and I nowhere assert that the tensions discussed in this Comment rise to the level of logical paradox. 
Rights clearly must give way in catastrophic cases, where harms of colossal proportion will be suffered unless some right is violated. For example, if stopping a terrorist from launching a salvo of nuclear missiles against China required killing several innocent hostages, it would be undeniably ${ }^{10}$ morally permissible-though nevertheless unfortunate-to sacrifice the hostages for the greater good. Even a healthy respect for the hostages' rights cannot suffer consequences of such magnitude. Catastrophic cases ${ }^{11}$ do not fundamentally challenge the notion that rights protect us from being sacrificed for the public good. Such cases merely reveal that rights have thresholds. ${ }^{12}$

Most "local or occasional necessities of the state,"13 however, are mundane by comparison. That is, the public good frequently wins out when no threat of true catastrophe exists. We can readily cull examples from the popular media. For instance, New York City currently is constructing City Tunnel No. 3, a water-supply tunnel linking the city to water in the Catskill Mountains. ${ }^{14}$ Twenty-four tunnel workers ("sandhogs") have died digging the tunnel thus far, and it is reasonable to expect that another forty-two will die before the project is completed-a rate of more than one worker death per mile. ${ }^{15} \mathrm{Al}$ -

${ }^{10}$ Where the choice of disparate harms is less extreme, the moral dilemma reemerges. See ThOMAS NAGEL, THE VIEW FROM NOWHERE 176 (1986) (discussing a situation in which twisting a child's arm will persuade the child's grandmother to tell you where her car keys are so you can go get help for several people seriously injured in a car accident).

"Schauer suggests that Dworkin and Nozick use the term "catastrophe" purposefully to invoke the mathematical literature on catastrophe. See Schauer, supra note 5, at 424 n.34. Schauer reports that the classic works in catastrophe theory include: RENE THOM, STRUCTURAL STABILITY AND MORPHOGENESIS (1975), and EDWARD ZEEMAN, CATASTROPHE THEORY (1977). See Schauer, supra note 5, at 424 n.34. Schauer also reports that A.G. WILSON, CATASTROPHE THEORY AND BIFURCATION 1-31 (1981) is useful. See Schauer, supra note 5, at 424 n.34.

${ }^{12}$ See, e.g., Samantha Brennan, Thresholds for Rights, 33 S.J. PHIL. 143 (1995) (developing a theoretic structure of rights and their thresholds and applying this structure to Judith Jarvis Thomson's threshold thesis). For a discussion of Thomson's threshold thesis, see infra notes 93-94 and accompanying text.

is 4 BLACKSTONE, supra note 1 , at *2.

" See Joel L. Swerdlow, Under New York, NAT'L GEOGRAPHIC, Feb. 1997, at 110, 115, 124 (describing the tunnel project); see also Alfred Lubrano, Water Tunnel Terror, NEWSDAY (N.Y.), Nov. 25, 1993, available in 1993 WL 11409390 (recounting a brief but informative history of the project).

${ }^{15}$ See Swerdlow, supra note 14, at 123-24. The accuracy of these numbers is questionable. New York City's Department of Environmental Protection, which oversees the project, put the death toll from "Stage One" of the work (1970-1986) at 19, although other published sources reported numbers as high as 23. See Lubrano, supra note 14 (setting forth these statistics). 
though the workers are aware of the risk ${ }^{16}$ and receive hazard pay, ${ }^{17}$ one misses much by appealing to traditional tort doctrines or imagining the catastrophe of New York City without water to explain the moral permissibility of New York City's actions.

To illustrate, assume that the value to the community of a new source of water, minus the financial costs of worker-safety measures, outweighs the expected costs in terms of human life resulting from the tunnel construction. That is, assume that whatever amount the city is spending to avoid worker death is sufficient. The legitimate value of a worker's life in this scheme is, let us say, $N$. (This reasoning is decidedly consequentialist.) Whatever the value of $N$, if even one worker were trapped in a cave-in, then any further building that would substantially risk death to this worker must stop, even if this would cost the city many times $N$-indeed, almost regardless of the cost. Rights-based norms prohibit "building over" the trapped worker, however expensive it is to remove her. This tension in the deontologist's views begs explanation.

Consider another example. Most people believe that the state may not intentionally incarcerate a person known to be innocent, even if a significant amount of crime would be deterred as a result of this one violation of rights. ${ }^{18}$ Nevertheless, as a general matter, it is

${ }^{16}$ Assumption of risk is an affirmative defense to tort liability. See, e.g., Krauth v. Geller, 157 A.2d 129, 130-31 (N.J. 1959) (discussing the public-policy reasons for the "fireman's rule" - the doctrine of assumption of risk as applied to public officials charged with maintaining public safety). Assumption of risk sometimes operates as a defense even against claims that otherwise would involve strict liability. See, e.g., RESTATEMENT (SECOND) OF TORTS $\$ 523$ (1977) ("The plaintiff's assumption of the risk of harm from an abnormally dangerous activity bars his recovery for the harm."). Assumption of risk as a legal doctrine probably is irrelevant to this example. State workers' compensation statutes preclude most workers from maintaining a cause of action for negligence against their employers. See, e.g., N.Y. WORK. COMP. LAW §§ 1011 (McKinney 1997) ("The liability of an employer prescribed by [section 10 of this article] shall be exclusive and in place of any other liability whatsoever ...."); Billy v. Consolidated Mach. Tool Corp., 412 N.E.2d 934, 936 (N.Y. 1980) (“As a general rule, when an employee is injured in the course of his employment, his sole remedy against his employer lies in his entitlement to a recovery under the Workers' Compensation Law....").

17 "An experienced tunnel worker earns more than $\$ 100,000$ a year." Swerdlow, supra note 14 , at 123 .

${ }^{18}$ Unsurprisingly, where it is discovered that an innocent person has been incarcerated, otherwise inviolable rules are set aside in order that they may be freed. See, e.g., Murray v. Carrier, 477 U.S. 478, 496 (1986) (noting that in an "extraordinary case, where a constitutional violation has probably resulted in the conviction of one who is actually innocent, [may] a federal habeas court [grant a habeas petition] in the absence of a showing of cause for the procedural default"). 
both legally and morally permissible to increase the penalties for crimes, create new crimes, increase funding for more police on the street, and the like even though such anti-crime policies will likely result in some innocent people being jailed. ${ }^{19}$ Examples of similar tensions are commonplace. ${ }^{20}$

${ }^{19}$ For obvious reasons, there are no reliable sources as to how many innocent people are currently imprisoned. It is eye-opening, however, that respectable scholars have claimed that 350 people have been wrongly convicted and sentenced to death in the United States since 1900 and that 23 of these innocent people have been executed. See Hugo Adam Bedau \& Michael L. Radelet, Miscarriages of Justice in Potentially Capital Cases, 40 STAN. L. REV. 21, 71 (1987) (setting forth these figures). This claim is particularly disturbing given the high standards required for death sentences and the relaxed standards for repeated appeal. Other scholars have questioned Bedau and Radelet's methodology and conclusions. See Stephen J. Markman \& Paul G. Cassell, Protecting the Innocent: A Response to the Bedau-Radelet Study, 41 STAN. L. REV. 121, 152 (1988) (arguing that the incapacitative, deterrent, and retributive functions served by capital punishment outweigh the cost of possibly executing innocent people). Bedau and Radelet responded to these criticisms in The Myth of Infallibility: A Reply to Markman and Cassell, 41 STAN. L. REV. 161 (1988).

${ }^{20}$ The recent controversy about air bags is another example. Right-based norms generally prohibit sacrificing one person to save others. Current air bag technology, however, does exactly that. On January 9, 1997, Andrew H. Card Jr., a representative of the American Automobile Manufacturers Association (AAMA), testified at the Air Bag Safety Hearings before the Senate Commerce Committee that "the performance needed to protect large unbelted adults increases the number of unbelted small children who are killed" by rapidly inflating air bags. Air Bag Safety: Hearing Before the Senate Comm. on Commerce, Science, and Transp., 105th Cong. 79 (1997) (statement of Andrew Card Jr., President and CEO, AAMA); see also John Mintz, NHTSA's Air Bag Standards Assailed; Hill Republicans Seek to End Rules Because of Dangers to Children, WASH. POST, Jan. 9, 1997, available in 1997 WL 2245248. Children in car seats who are killed by rapidly inflating air bags probably would not have been killed otherwise. See id. Thus, children's lives are being traded for the lives of many more adults.

Notice that the air bag controversy does not center around this choice. Rather, the debate arose because these additional deaths are prima facie preventable. The National Highway Traffic Safety Administration (NHTSA) has taken steps to cure this problem. NHTSA has proposed amending the agency's occupant crash protection standard to ensure that vehicle manufacturers can mechanically alter all air bags so that they inflate less aggressively. See Federal Motor Vehicle Safety Standards; Occupant Crash Protection, 62 Fed. Reg. 807, 815 (1997) (to be codified at 49 C.F.R. pt. 571) (proposed Jan. 6, 1997). Other regulatory steps have already been taken. Vehicle manufacturers are permitted to offer manual cutoff switches for the passenger-side air bag for those cars that do not accommodate rear-facing infant seats. See Federal Motor Vehicle Safety Standards; Occupant Crash Protection, 62 Fed. Reg. 798, 799 (1997) (to be codified at 49 C.F.R. pt. 571) (extending this rule to September 1, 2000). NHTSA also has required warning labels stating "Children Can Be Killed or Injured by Passenger Air Bag." Federal Motor Vehicle Safety Standards; Occupant Crash Protection, 62 Fed. Reg. 31, 33 (1997) (to be codified at 49 C.F.R. pt. 571). Additionally, NHTSA has issued a proposal to make it possible for vehicle owners to have their air bags deactivated by vehicle dealers and repair businesses. See Air Bag Deactivation, 62 Fed. Reg. 831 (1997) (to be codified at 49 C.F.R. pt. 595) (proposed Jan. 6, 1997). 
These cases raise the issue of when rights operate to protect the individual from the demands of society, and when, conversely, society's interests come first. This question is about the relationship between morality and societal control. In our society, law is infused, both theoretically and practically, with morality. The common law has evolved largely in accord with moral intuitions, the Constitution is infused with moral concepts, and legislative debates often center on moral disputes. To understand existing law, we cannot ignore the strictures and freedoms of morality. Moreover, we should not ignore the interplay between law and morality. Law is not merely a collection of black letters or an abstract theoretic system. Rather, law is the most basic symbol of who we are as a people, our grandest totemic representation. The nature of the right and the good therefore deserve the utmost consideration within legal scholarship.

The issues addressed in this Comment are theoretical, and their resolution is not amenable to a factual taxonomy. Thus, the discussion below, a search for plausible and structured limits on governmental action, is necessarily quite abstract. This Comment is premised on deontology. ${ }^{21}$ That is, I assume here that, even if a deflationary metaphysical account must ultimately be given for them, rights "exist" at the very least for the purposes of applied ethics. Thus, I begin in Part I by offering a very brief introduction to deontology. In Part II, I canvas two leading theories of rights. I first outline Ronald Dworkin's views on legal rights, and then Judith Jarvis Thomson's views on moral rights. Although useful for deepening our understanding of rights as such, I show that neither account answers the questions posed in this Introduction. In Part III, I defend the notion that deontology does not exhaust moral discourse. I first argue for this limitation as a matter of theory, and then outline several types of cases recognized in the philosophical literature in which deontological norms do not apply. Part IV introduces and gives an extended discussion of the "distributive exemption." This exemption to deontological norms is illustrated by the well-known "Trolley Problem." In Part V, I argue that the criteria that trigger the distributive exemption are found in society generally. This insight permits a new justification for the existence of the coercive state, both in conjunction with traditional social contractarian assumptions, and after relaxing these assumptions and taking the modern state "as is." By applying

${ }^{21}$ Deontology is defined below. See infra Part I. For now, it is sufficient to note that deontology is a right-based theory of the good. 
the distributive exemption to the state, this Comment also explains how deontology permits the sort of consequentially justified policy choices most people intuitively accept as correct, but which are in prima facie tension with deontological norms as illustrated by the examples above. It is important to notice that this largely consequentialist conclusion is derived from within a deontological framework.

\section{DEONTOLOGY GENERALLY}

Deontology is the theory of moral obligation, and, by connotation, encompasses moral theories that emphasize rights and duties. Put another way, deontological theories are those moral theories of a vaguely Kantian stripe. Kant held that one should "[a]ct in such a way that [one] always treat[s] humanity, whether in [one's] own person or in the person of any other, never simply as a means, but always at the same time as an end." It was not always so. When Jeremy Bentham, one of utilitarianism's founders, first coined the word in $1814,{ }^{23}$ "deontology" referred to the marshaling of self-interested reasons for agents to act for the general good. ${ }^{24}$ Essentially, this was a utilitarian theory of obligation, and was quite distinct from modern use. $^{25}$

22 IMMANUEL KANT, GROUNDWORK OF THE METAPHYSIC OF MORALS 96 (H.J. Paton trans., Harper \& Row 1964).

${ }^{23}$ See Amnon Goldworth, Introduction to JEREMY BENTHAM, DEONTOLOGY TOGETHER WITH A TABLE OF THE SPRINGS OF ACTION AND THE ARTICLE ON UTILITARIANISM at xix-xx (Amnon Goldworth ed., 1983) [hereinafter DEONTOLOGY] (noting that the term "deontology" first appeared in Bentham's works at this time). The word was

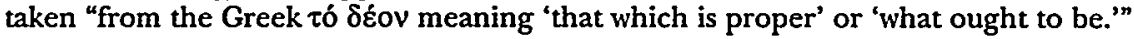
Id. at xix.

${ }^{24}$ Bentham's view was that each person's interest, rightly understood, coincided with moral obligation or duty. See JEREMY BENTHAM, Deontology, in DEONTOLOGY, supra note 23, at 117, 121 ("[A]11 laws, in so far as they have for their object the happiness of those concerned, have for their endeavour to cause it to be for a man's interest to do that which they make it his duty to do, and thus to bring his interest and his duty into coincidence."). According to Professor Gerald Postema, Bentham's "technique of deontology is to mobilize reasons of private (though perhaps hidden or long-range) interest already available to the agent." Gerald J. Postema, Bentham, Jeremy (1748-1832), in 1 ENCYCLOPEDIA OF ETHICs 85, 88 (Lawrence C. Becker ed., 1992). For Bentham's approximation of a definition of "deontology," see BENTHAM, supra, at 124.

${ }^{25}$ Bentham famously thought that rights, a common element of modern-day deontological theories, were "nonsense upon stilts." 2JEREMY BENTHAM, Anarchical Fallacies, in THE WORKS OF JEREMY BENTHAM 489, 501 (John Bowring ed., London, Simpkin, Marshall, \& Co. 1843); see DWORKIN, supra note 3, at 184 (restating Bentham's view). 
Modern-day deontologists focus much attention on rights. ${ }^{26}$ It might be thought that this focus is merely a preference, for rights are often taken to be correlative with duties. For example, where this relation holds, if I have a right not to be punched, you are under an obligation not to punch me, and conversely. Thus, deontology may be articulated through either related element. More generally, in theories holding that rights and duties are correlative, one may give an account of rights and then define duties by reference to rights; one may define rights in terms of an antecedent theoretic account of duties; or one may give separate theoretic accounts of rights and duties. ${ }^{27}$

Rights need not be completely correlative with duties. ${ }^{28}$ For example, take the notion of privileges, understood here as a subspecies of rights. The lone occupant of a small and isolated island presumably possesses a privilege to sing show-tunes at the top of her voice. ${ }^{29}$

${ }^{26}$ See, e.g., JOEL FEINBERG, RIGHTS, JUSTICE, AND THE BOUNDS OF LIBERTY (1980) (delineating in a collection of essays an approach to the nature and value of rights); NEIL MACCORMICK, LEGAL RIGHT AND SOCIAL DEMOCRACY (1982) (arguing for a state in which rights are balanced with egalitarian goals); D.N. MacCormick, Rights in Legislation, in LAW, MORAIITY, AND SOCIETY 189, 192 (P.M.S. Hacker \& J. Raz eds., 1977) (rejecting a "will theory" and advancing an "interest theory" of rights in legislation); J.L. Mackie, Can There Be a Right-Based Moral Theory?, 3 MIDWEST STUD. PHIL. 350, 358 (1978) (discussing various approaches to rights and providing a "tentative initial sketch of a right-based moral theory"); J. Raz, Legal Rights, 4 OXFORD J. LEGAL STUD. 1 (1984) (discussing various philosophical approaches to rights and distinguishing between "legal rights" and "legally-respected rights"); J. Raz, On the Nature of Rights, 93 MIND 194, 194 (1984) (offering "an account of the nature of rights" and "the philosophically significant aspects... : the capacity to have rights and the relations between rights, duties, and interests").

${ }^{27}$ A proponent of the third alternative would be pressed to offer a deeper account of the otherwise amazing coincidence that rights in fact are typically correlative with duties. Doing this in a way that would preserve the distinct theoretic underpinnings of rights and duties is no small task, for it seems likely that any plausible explanatory account of rights would mirror an explanatory account of obligations. Although the theoretic obstacles are daunting, this third view remains a logical possibility.

${ }^{23}$ See THOMSON, supra note 7 , at 52,56 (stating that privileges are rights and are not correlative with duties).

${ }^{29}$ The influential turn-of-the-century legal theorist Wesley Newcomb Hohfeld believed that legal rights can be distinguished into claims (i.e., rights, strictly speaking), privileges, powers, and immunities. With respect to this example, Hohfeld would say that this privilege to sing show-tunes is not a right, strictly speaking. The reason for this, however, is that, for Hohfeld, it is definitionally true that rights are correlative with duties. See WeSLEY NEWCOMB HOHFELD, FUNDAMENTAL LEgal CONCEPTIONS AS APPLIED IN JUDICIAL REASONING 38 (Walter Wheeler Cook ed., 1919) ("[I]f $X$ has a right against $Y . .$. , the correlative (and equivalent) is that $Y$ is under a duty toward $X$ ...."). Thus, in Hohfeld's view, privileges are not rights. See id. at 39 (stating that the fundamental difference between a right and a privilege is that the correlative of a privilege is not a duty but a "no right"). 
This right, however, has no correlative obligation. It is not just that the island, being otherwise deserted, has no one in whom the obligation inheres. Rather, it is a structural feature of the example that no obligation not to interfere can exist. Introducing another person onto the island would destroy the privilege, for it would be immoral for the singer to subject another person to her showmanship without the other person's consent.

Likewise, there may be obligations for which correlative rights do not exist. For example, one may be under an obligation to write letters to her grandfather without her grandfather having the right to receive letters written by his granddaughter. ${ }^{30}$ "Omissions" may also be understood as obligations for which there are no corresponding rights. If you may easily save somebody from great harm or death without substantial risk to yourself, a moral obligation exists to so help them. ${ }^{3 l}$ Most people, however, do not think that the victim has a right to your efforts. ${ }^{32}$ Although more could be said, my point is that whether or not one takes rights to be correlative with duties has implications for other aspects of moral theory.

For the purposes of this Comment, there is no need to trace the contours of deontology with precision. Thus, although it is a simplification, this Comment will focus only on rights. The ultimate goal, again, is to discover when we may appeal to rights as a way of protecting ourselves against the demands of society. The next Part examines the nature of rights more closely.

\section{RIGHTS}

Although many authors have contributed to the discussion of rights, ${ }^{33}$ I have narrowed my focus to two influential accounts: Ronald Dworkin's views on legal rights and Judith Jarvis Thomson's views on

so See, e.g., THOMSON, supra note 7, at 117 (noting that norms of generosity, kindness, helpfulness, and thoughtfulness impose obligations with no corresponding rights).

${ }^{31}$ Much has been written about omission liability. See 1 JOEL FEINBERG, THE MORAL LIMITS OF THE CRIMINAL LAW 126-86 (1984) (giving a relatively comprehensive discussion of omission liability); Frank E. Denton, The Case Against a Duty to Rescue, 4 CANADIAN J.L. \& JURIS. 101 (1991); Heidi M. Malm, Liberalism, Bad Samaritan Law, and Legal Paternalism, 106 ETHICS 4 (1995) (arguing that even if morally legitimate, omission liability weakens the commitment to neutrality, alters the conception of autonomy, and undesirably increases legal paternalism-all anathema to liberalism).

${ }^{32}$ See, e.g., THOMSON, supra note 7, at 160-63 (offering arguments as to why rights cannot be held against omissions).

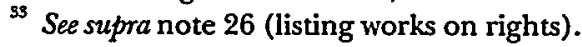


moral rights. As will emerge from the exegesis of this Part, neither Dworkin's nor Thomson's view of rights gives structured answers to the questions posed by this Comment.

\section{A. Dworkin's Account of Legal Rights}

Dworkin's project is a broad one; he seeks to construct a "liberal theory of law," judges deciding "hard cases." 35 Hard cases, for Dworkin, are those in which no clear rule of law determines the outcome. ${ }^{36}$ In such cases, Dworkin holds that the morally proper outcome determines legal rights. ${ }^{37}$ For Dworkin, the line between the legal and the moral in our culture is eviscerated to some degree. ${ }^{38}$ One reason for this is that the Constitution, our final legal authority, "fuses legal and moral issues, by making the validity of a law depend on the answer to complex moral problems."

Rights, for Dworkin, are understood functionally through their distributional character, and are distinguished from goals. ${ }^{40}$ Take first the distributional character of collective goals. These goals seek to achieve some particular, even if vaguely defined, distribution within

${ }^{34}$ DWORKIN, supra note 3, at vii.

${ }^{35}$ See id. at 105-30 (building his theory through discussion of the hypothetical and philosophical judge "Hercules"). More directly, Dworkin defines legal rights as "institutional right[s] to the decision of a court in its adjudicative function." Id. at xii (emphasis added).

${ }^{36}$ See id. at 81 .

${ }^{37}$ See id. ("I shall argue that even when no settled rule disposes of the case, one party may nevertheless have a right to win.").

${ }^{s 3}$ The qualifier "to some degree" is necessary for two reasons. First, not all moral rights are legal rights. Dworkin acknowledges that sometimes legal and moral rights genuinely will conflict. See id. at 126-27 (discussing what a morally responsible judge's approach to such a case should be). Second, not everything that is a legal right, even a constitutional right, is a moral right. See id. at 191. Borrowing Dworkin's examples, the right to drive either way on 57th Street and the right to vote for a congressperson every two years instead of, for example, every four years, are legal but not moral rights. See id. In principle, the government would not be acting wrongly if it altered these rights. See id.

${ }^{39}$ Id. at 185; see id. at 208 ("The constitution makes our conventional political morality relevant to the question of validity; any statute that appears to compromise that morality raises constitutional questions, and if the compromise is serious, the constitutional doubts are serious also.").

${ }^{10}$ See id. at 90 ("I shall distinguish rights from goals by fixing on the distributional character of claims about rights, and on the force of these claims, in political argument, against competing claims of a different distributional character."). 
the society. ${ }^{41}$ For example, Dworkin notes that economic efficiency is a collective goal. ${ }^{42}$ Importantly, with respect to collective goals, "distributional principles are subordinate to some conception of aggregate collective good, so that offering less of some benefit to one [person] can be justified simply by showing that this will lead to a greater benefit overall.".43 Hence, the collective goals of a community are appropriate fodder for consequentialist reasoning.

Rights, however, have a different distributional character. As Dworkin states: "If someone has a right to something, then it is wrong for the government to deny it to him even though it would be in the general interest to do so.". ${ }^{44}$ Put another way, the right is prior to the good. ${ }^{45}$ Thus, for Dworkin, "individual rights are political

${ }^{11}$ For a fuller discussion, see $i d$. at 91.
${ }^{42}$ See $i d$.
${ }^{45} I d$.
${ }^{4} I d$. at 269 .
${ }^{5}$ Modern philosophical parlance has taken to distinguishing theories according to their prioritizing of the right and the good. See, e.g., JOHN RAWLS, A THEORY OF JUSTICE 24 (1971) ("The two main concepts of ethics are those of the right and the good .... The structure of an ethical theory is, then, largely determined by how it defines and connects these two basic notions."). Philosophers generally understand "the

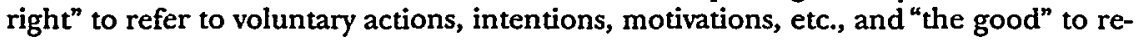
fer to those things that are intrinsically valued. See, e.g., Mark Sagoff, The Limits of Justice, 92 YALE L.J. 1065, 1066 (1983) (reviewing MICHAELJ. SANDEL, LIBERALISM AND THE LIMITS OF JUSTICE (1982)) ("As philosophical terms, 'rightness' pertains to voluntary actions, while 'goodness' pertains to the consequences of those actions."). It is clear in context that Sagoff correctly understands that the evaluation of consequences is measured against an ideal, such as happiness or the satisfaction of desire.

The distinction between the right and the good is quite useful because it allows a clear distinction to be drawn between consequentialism and deontology. Consequentialist theories are those in which the good is "defined independently from the right, and then the right is defined as that which maximizes the good." RAWLS, supra, at 24. It should be noted that Rawls as quoted here refers to the "teleological theories" as defined in WilliaM K. FRANKena, Ethics 13 (1963). According to Frankena, "[a] teleological theory says that the basic or ultimate criterion or standard of what is morally right, wrong, obligatory, etc., is the nonmoral value that is brought into being." Id. "Teleological theories" constitute a potentially infinite class, of which classical utilitarianism is a single member. Utilitarianism achieves its distinctive flavor by identifying desire-satisfaction as the good. Cf. RAWLs, supra, at 25 (listing briefly other moral theories such as hedonism and perfectionism resulting from other conceptions of the good).

Deontological theories either do "not specify the good independently from the right, or [do] not interpret the right as maximizing the good." Id. at 30. Rather, "[d]eontological theories hold that there are ethical propositions of the form: 'Such and such a kind of action would always be right (or wrong) in such and such circumstances, no matter what its consequences might be." C.D. BROAD, FIVE TYPES OF ETHICAL THEORY 206 (1934). Rawls is right to note, however, that "deontological 
trumps held by individuals. ${ }^{, 46}$

Dworkin draws various distinctions within the class of political rights. ${ }^{47} \mathrm{He}$ claims, inter alia, that there are both concrete rights and abstract rights. Concrete rights are "political aims that are more precisely defined so as to express more definitely the weight they have against other political aims on particular occasions." ${ }^{\text {"48 }}$ In contrast, an abstract right "is a general political aim the statement of which does not indicate how that general aim is to be weighed or compromised in particular circumstances against other political aims." ${ }^{49}$ Examples of abstract rights include "[t]he grand rights of political rhetoric" such as "free speech or dignity or equality." Abstract rights obviously overlap significantly with moral notions. ${ }^{51}$ Abstract rights "provide arguments for concrete rights, but the claim of a concrete right is more definitive than any claim of abstract right that supports it. ${ }^{52}$ For example, the right of privacy is an abstract right, but the right of a woman to abort her fetus in the first trimester of pregnancy is a concrete privacy right.

Dworkin also draws a separate, though overlapping, distinction between background rights and institutional rights. Background rights "provide a justification for political decisions by society in the abstract." ${ }^{53}$ Background rights will often, though not always, depend upon abstract rights. An institutional right provides "justification for

theories are defined as nonteleological ones, not as views that characterize the rightness of institutions and actions independently from their consequences. All ethical doctrines worth our attention take consequences into account in judging rightness." RAWLS, supra, at 30.

${ }^{46}$ DWORKIN, supra note 3 , at xi.

${ }^{17}$ Dworkin draws four explicit distinctions between types of rights in chapter four of Taking Rights Seriously. See id. at 81-130. In addition to the distinctions discussed below between abstract and concrete rights, and between background and institutional rights, Dworkin distinguishes rights held against the state from rights held against other citizens, and distinguishes universal and special rights. See id. at 93-94, 94 n.1.

${ }^{48}$ Id. at 93.

${ }^{49} I d$.

${ }^{50} I d$.

${ }^{51}$ See, e.g., id. at 326 ("Background moral rights enter ... into the calculation of what legal rights people have...., and ... some positivists' thesis, that legal rights and moral rights are conceptually distinct, is therefore wrong." ).

${ }^{52}$ Id. at $93-94$.

${ }^{53}$ Id. at 93 (noting that some political theory might hold as a background right that "every [person] has a right to the property of another if he needs it more," while also recognizing that this principle might not be instantiated in any institutional rights). 
a decision by some particular and specified ... institution. ${ }^{{ }^{54}}$ Institutional rights, of which legal rights are one sort, are still "genuine rights" and have trumping effect. ${ }^{55}$

These distinctions afford Dworkin a concise way of defining legal rights. "Legal rights may then be identified as a distinct species of a political right, that is, an institutional right to the decision of a court in its adjudicative function. ${ }^{256}$ Thus, "judges decide hard cases by confirming or denying concrete rights. ${ }^{57}$ In so doing, judges may appeal to background principles. Ultimately, however, the judgment must either confirm or announce "institutional rather than background rights, and they must be legal rather than some other form of institutional rights. ${ }^{\text {} 58}$

This Comment addresses the relationship between rights and the sometimes consequentialist demands of society. Dworkin's account of rights has not clarified this issue. We cannot look to institutional rights to indicate when the state permissibly may act, for institutional rights are precisely those rights that the state declares that we possess. Although Dworkin's background rights or collective goals might, in principle, be used to carve out exceptions to deontological norms suf-

${ }^{54}$ Id. The ellipsis hides the word "political." Institutional rights may, but need not, depend on political institutions. See id. at 101 (discussing the institution of the game of chess). Institutions may be fully or partially autonomous. See id. In a fully autonomous institution, "no one may claim an institutional right by direct appeal to general morality." Id. Political institutions are only partly autonomous. See id. (explaining, in the context of legislation, that "[c]itizens are expected to repair to general considerations of political morality when they argue for" the "right to have a certain statute enacted"). This partial autonomy is somewhat responsible for the relative social stability of our society. That the law is partially derivative from moral claims gives us moral and psychological reasons to respect the law. See id. at 184 (noting that the fact that "citizens have some moral rights against their Government .... [is] a point of pride .... [for many who thus conclude that] our law deserves respect"). The fact that the law is only partially autonomous, however, also helps account for this stability. The law serves an "insulating" function by shielding officials from what otherwise might be the incessant moral demands of citizens divided in their moral views. The "infinite semantic depth" found in the vagueness of those parts of the Constitution that incorporate moral principles (both textually and structurally) allows an extremely broad cross-section of society to regard the Constitution as normatively authoritative. The phrase "infinite semantic depth" is borrowed from Thomas C. Grey, The Constitution as Scripture, 37 STAN. L. REV. 1, 22 (1984), who argues that the premises for constitutional interpretation come from sources outside the Constitution. See also Sanford Levinson, "The Constitution" in American Civil Religion, 1979 SUP. CT. REV. 123 (discussing the analogy between Scripture and the text of law).

${ }_{55}$ See DWORKIN, supra note 3, at 101.

${ }^{36}$ Id. at xii.

${ }^{37}$ Id. at 101.

${ }^{33} I d$. 
ficient to account for cases like those in the Introduction to this Comment, Dworkin's account is vague on this point. Thus, even if Dworkin's account of legal rights might be used to mark the boundaries between rights and policy needs, Dworkin has not explained how this would work, nor is this evident from the face of his views.

Moreover, that Dworkin's background rights and abstract rights have influence over concrete rights and institutional rights should be somewhat troubling to a purebred deontologist. Background and abstract rights are essentially general policy aims. By their very nature, aims are appropriately weighed against other goals to determine what behavior or policy is appropriate. Such a project looks consequentialist in nature and makes Dworkin resemble a rule-consequentialist. ${ }^{59}$ Dworkin remains skeptically agnostic on this point; he acknowledges that goals might inform policy at some deep level, although he still insists that there is a common-sense distinction to be drawn between policy and principle. ${ }^{60}$ Again, however, Dworkin's views lack the specificity that would allow the deontologist to make the sort of principled policy decisions sought in the Introduction to this Comment.

\section{B. Thomson's Account of Moral Rights}

Judith Jarvis Thomson presents her theory of rights in The Realm of Rights, a more complete version of her earlier views on rights. ${ }^{61} \mathrm{Al}$ though Thomson focuses on morality instead of law, ${ }^{62}$ she believes that law and morality overlap extensively and denies that rigid distinctions between the two can be drawn. ${ }^{6 s}$ Thomson's concern, therefore, is to construct a theory of rights simpliciter, of which there are legal and moral aspects.

${ }^{59}$ Rule-consequentialism is the view that one should act in accordance with those rules that would tend to maximize the good if followed. The rules might take the form of "Do not kill an innocent person," or other deontologically styled maxims. See, e.g., T.M. Scanlon, Rights, Goals, and Faimess, in CONSEQUENTIALISM AND ITS CRITICS, supra note 6 , at 74,75 (arguing that rights can be best understood on the two-tiered model of rule-utilitarianism).

${ }^{60}$ See DwORKIN, supra note 3, at 96 (distinguishing arguments of principle from arguments of policy). Dworkin is less agnostic elsewhere. See RONALD DWORKIN, LAW'S EMPIRE 290-91 (1986) (arguing against rule-utilitarianism).

${ }^{61}$ An example of her earlier views may be found in Judith Jarvis Thomson, Some Ruminations on Rights, 19 ARIZ. L. REV. 46 (1977), reprinted in JUDITH JARVIS THOMSON, RIGHTS, RESTITUTION, AND RISK 49 (William Parent ed., 1986).

${ }_{62}$ THOMSON, supra note 7, at 73 ("It is morality, ... not law, that interests us.").

6s See id. at 73-76 (noting that "legal rights and moral rights are [not] two distinct species of the genus rights" and stating that "some of our rights certainly seem to have both legal and nonlegal sources"). 
In my Introduction, I briefly questioned how it might ever be right to produce less good, rather than more. ${ }^{64}$ Thomson views the appeal underlying this query, the motivating idea behind consequentialism, as mistaken because it rests on the false belief "that value is what all morality reduces to. ${ }^{65}$ Thomson asserts that " $[t]$ here is more to morality than value: there are also claims"

Thomson takes it as a brute fact that the moral realm includes rights, ${ }^{67}$ in the sense that rights are necessary truths. ${ }^{68}$ Thomson understands necessity here linguistically, asserting that rights claims are analytically true. ${ }^{69}$ Her view, however, is not that statements of rights are analytically true in the trivial sense that "a bachelor is an unmarried man" is almost universally thought to be. ${ }^{70}$ Rather, Thomson relies on philosopher and logician Saul Kripke, who propounds, in her

See supra note 2 and accompanying text.

${ }^{65}$ THOMSON, supra note 7 , at 148.

"6 Id.; see also id. at 165 (noting that a "theory of rights must tell us what the moral significance of a claim is").

${ }^{67}$ Thomson does not argue that one cannot theoretically explain the existence of rights. Rather, she seems merely not to view it as her project in the works here discussed. See id. at 357 (conceding the possibility that a rule-utilitarian account of rights might be given); see also id. at 30 n.19 (noting that Scanlon's rule-utilitarian thesis might be a necessary truth).

${ }^{\text {} S}$ See id. at 18 (noting that rights statements, such as "[o]ther things being equal, one ought not cause others pain," could not have failed to be true).

${ }^{69}$ See id. (claiming that "a statement is a necessary truth if and only if it is 'analytic').

${ }^{70}$ Thomson's presumption that analyticity is commonplace seems too cavalier. It is very difficult to find true analytic statements, other than the postulated or derived truths of mathematics and science. For example, is it really so obvious that a homosexual male in a long-term monogamous relationship is a bachelor, despite the fact that he satisfies the definition? Moreover, what about hermaphrodites? If analyticity is problematic even in straightforward, "trivially true" necessary statements, it is difficult to believe that all rights, many of which are contextually sensitive to situational complexities, can be parsed as analytic statements in any informative way. Thomson may of course make it definitionally true that $A$ has a right to $p$ in a given context, but doing so is neither interesting nor enlightening. To be fair, I should note that the paradigmatic example in the text is usually phrased "All bachelors are unmarried," which ostensibly is analytically true. See id. at 18-19; see also WILLARD VAN ORMAN QUINE, WORD AND OBJECT 66 (1960) ("No bachelor is married."). But depart ever so slightly from this phrasing to the putatively cognitively synonymous statement of the text and the problems identified above abound. See WILLARD VAN ORMAN QUINE, Two Dogmas of Empiricism, in FROM A LOGICAL POINT OF VIEW 20 (2d ed. rev. 1980) [hereinafter Two Dogmas] (arguing in part against the analytic/synthetic distinction); LuDWIG WITTGENSTEIN, The Blue Book, in THE BLUE AND BROWN BOOKS 1, 25 (1964) ("We are unable clearly to circumscribe the concepts we use; not because we don't know their real definition, but because there is no real 'definition' to them."). I think that the best way to read Thomson is to ignore the metaphysical basis of her views and note that she takes rights as given. 
opinion, a "very convincing[]" defense of the necessity encompassed in statements such as "Water is $\mathrm{H}_{2} 0$." Kripke's theory of reference is built on the causal genesis and use of words, and is expressed in a modally realist fashion employing counterpart theory or transworld identity. ${ }^{72}$ If, as she adverts, Thomson is following Kripke, her claim is that the word "rights" rigidly designates the sort of thing encompassed in "[o]ne ought not torture babies to death for fun." A term is a "rigid designator if in every possible world it designates the same object." Thomson expresses some reluctance about saying too much about these matters, ${ }^{75}$ and thus it would be unfair to attribute too many details of Kripke's thought to her. ${ }^{76}$ For the purposes of this Comment, no harm ensues from an exegesis that goes no deeper than accepting that Thomson takes rights as given.

At the level of greatest generality, "[t]o have a right is to have a kind of moral status." For Thomson, a right is simply a behavioral constraint. $^{78}$ If one person holds a rights claim against another, that

7 See THOMSON, supra note 7, at 19 (discussing SAUL A. KRIPKE, NAMING AND NECESSITY (1972), and using his examples of statements constituting necessary truths).

72 See SAUl A. KRIPKE, NAMING AND NECESSITY 22-70 (2d ed. 1980).

73 THOMSON, supra note 7 , at 18.

${ }^{74}$ KRIPKE, supra note 72, at 48. Kripke's causal account of reference is most amenable to proper names, although I see no reason why it could not be tailored to accommodate very general notions like morality. So although Thomson's claim does not fit neatly into the language I quote from Kripke, this problem is probably not damning.

${ }^{75}$ See THOMSON, supra note 7, at 19 ("What we should think of the view that a statement is a necessary truth only if it is analytic is a larger issue than I can deal properly with here ....").

${ }^{76}$ Thomson's reliance on Kripke probably does not relieve her from my objection to her presumption that all rights claims can be parsed as interesting analytic truths. See supra note 70. Thomson might take rights claims to be true because they anchor a discussion, similar to the way that a description which "fixes a referent" without being definitionally synonymous does. See KRIPKE, supra note 72, at 54-63 (discussing, inter alia, Wittgenstein's meter bar). This is a more interesting claim than simply stating that rights claims are definitionally true. It does not, however, go further than accepting certain rights as given, or else it falls subject to the problems inherent in cognitive synonymy discussed earlier. See supra note 70 . Thomson might instead assert that the truth of rights claims might be discovered in all worlds by (moral) observation. This kind of empirical confirmation, however, is subject to Quine's objection against using empirical verification to undergird analyticity. See Two Dogmas, supra note 70, at 37-42.

77 THOMSON, supra note 7, at 38.

${ }^{78}$ See id. at 79. This proposition is stronger than an argument that the existence of a right entails behavioral constraints. For Thomson's justifications of this view, see id. at 79-87, 120-22. 
other person is under a moral obligation to accord the claim. ${ }^{79}$ Where necessity dictates that a right simply must be infringed, a release "ought" first be obtained. ${ }^{80}$ Where obtaining this release is impossible, Thomson asserts that compensation must be made for any harms or losses causally resulting from the infringement. ${ }^{81}$

Thomson draws a distinction between violating a right and merely infringing a right. A person infringes a right when she permits the state of affairs that was part of the content of the right to fail to obtain. $^{82}$ Thus, if Joe has a right that $p$ obtain, and $p$ does not obtain, Joe's right has been infringed. ${ }^{83}$ A person violates a right when she infringes a right and ought not have.

Thomson is not an absolutist with respect to rights. ${ }^{85}$ For Thomson, that someone has a right to something does not automatically imply that this right can never be infringed regardless of the costs to others. ${ }^{86}$ Determining when infringement of a right is per-

${ }^{79}$ Thomson discusses this point in chapter three of The Realm of Rights. See id. at 79. She represents the idea as follows: "If there is an X such that $\mathrm{C}_{\mathrm{X}, \mathrm{Y}} \mathrm{P}$, then $\mathrm{Y}$ ought" to accord p. Id. at 81. Quantifying over $X$ and $Y$ in the traditional manner would narrow Thomson's statement such that a single quantification could no longer represent all rights. For example, $(\exists X)(\forall Y)\left(C_{X Y} p \supset_{\text {ovart }} A_{y} p\right)$, where $A_{y} p$ represents $Y$ accords $p$, and where $p$ is satisfied only if $p$ obtains with respect to $X$, may be precise, but it only describes rights that an individual holds against the world. Not all rights are so held. For instance, where the statement is true of a particular instantiation of $Y$ only because $Y$ owes a duty to $X$ (as when $Y$ promises $X$ something), then existential quantification over $Y$ would be appropriate. Similarly, some rights inhere in all and thus are better described by universally quantifying over $X$. Although Thomson's notations are truncated to introduce a proper level of ambiguity, there is no present benefit in being precise with future representations. For most purposes here, even Thomson's limited notation will not be followed.

${ }^{80}$ See id. at $92-95$.

${ }^{81}$ See id. at 91-97. Thomson's discussion is built around Vincent $v$. Lake Erie Transportation Co., 124 N.W. 221 (Minn. 1910), in which a shipowner was required to pay compensation after prudently remaining moored to a loading dock in a storm, damaging the dock. She relies, in part, on Richard A. Epstein, A Theory of Strict Liability, 2 J. LEGAL STUD. 151 (1973), which also discusses Vincent.

${ }^{82}$ See THOMSON, supra note 7, at 122.

"As Thomson notes, $p$ can be negative, such as "Y's staying off X's land." See id.

${ }^{84}$ See id. ("Y has violated X's claim against $\mathrm{Y}$ only if it is not merely true that $\mathrm{Y}$ let $\mathrm{S}$ fail to obtain but more, that Y ought not have let S fail to obtain.").

${ }^{85}$ This conclusion is supported by the fact that Thomson decries the usefulness of talking about prima facie rights, denying that such a discussion might be a conceptual advance. See id. at 120-22 (noting that "nothing seems to be gained by accepting the thesis that all claims are absolute").

${ }^{86}$ See id. at 114 (stating that "it might be impermissible for you to prevent a person from infringing a claim of yours"). 
missible depends on what Thomson calls the "Tradeoff Idea." ${ }^{87}$ The Tradeoff Idea holds that "[i] $t$ is permissible to infringe a claim if and only if infringing it would be sufficiently much better for those for whom infringing it would be good than not infringing it would be for the claim holder." ${ }^{\$ 8}$ Because the Tradeoff Idea merely makes it morally permissible to infringe a right, Thomson's view is theoretically distinct from the act-consequentialist mandate to infringe rights in such cases. $^{89}$

The linchpin of the Tradeoff Idea- "sufficiently much better"-is a fuzzy notion in at least four respects, the third and fourth being most important. First, there is no fixed amount of good sufficient to trigger the Tradeoff Idea; the threshold will not remain constant in absolute terms. Thomson makes this point by saying that some rights are more "stringent" than others. ${ }^{90}$ Although Thomson expresses it more rigorously, the idea is that one rights claim is more stringent than another if it takes more good to render its infringement permissible. ${ }^{\text {91 }}$ Rights to life, for example, are more stringent than rights against trespass.

Second, the manner in which something must be better is left unspecified. The Tradeoff Idea might be sensitive to all values, or merely some. Answering this question determines whether convenience, for example, will be sufficient to trigger a Tradeoff.

The third and fourth ways in which "sufficiently much better" is vague pertain to the differential required to trigger the Tradeoff Idea. Thus, third, it is possible to understand the Tradeoff Idea such that only a little bit "better" is sufficient to trigger a Tradeoff. Thomson, like any good deontologist, rejects this notion, at least for more stringent claims. ${ }^{92}$ The smaller the differential sufficient to trigger a

${ }^{87}$ See id. at 123.

${ }^{88}$ Id. at 153.

${ }^{89}$ See id. at 123-24 (comparing the permissive nature of the Tradeoff Idea to the mandatory nature of consequential act-utilitarianism).

${ }^{90}$ See id. at 154 (suggesting that "the stringency of a claim itself [varies] with how bad its infringement would be for the claim holder").

${ }^{91}$ Thomson expresses this notion in part through the "Comparison Principle." See id. Thomson explains the Comparison Principle as follows:

Suppose $X_{1}$ has a claim against $Y_{1}$ that $Y_{1}$ do alpha, and $X_{2}$ has a claim against

$Y_{2}$ that $Y_{2}$ do beta. Then $X_{1}$ 's claim against $Y_{1}$ is more stringent than $X_{2}$ 's claim

against $Y_{2}$ if and only if $Y_{1}$ makes things worse for $X_{1}$ if $Y_{1}$ fails to do alpha than Id.

$\mathrm{Y}_{2}$ makes things for $\mathrm{X}_{2}$ if $\mathrm{Y}_{2}$ fails to do beta.

${ }^{92}$ See id. at 168 (noting that many claims are "maximally stringent" and cannot be infringed). 
Tradeoff, the less difference there is between the resulting understanding of rights and consequentialism.

Fourth, and finally, the notion is fuzzy because for whom the Tradeoff must be "sufficiently much better" is flexible. This is essentially a distribution requirement. Benefiting one person by infringing a right in a given context creates a certain amount of good. One might believe that if this benefit instead accrues to two, there is twice as much good. If so, a Tradeoff that was impermissible in the first case might be permissible in the second. Thomson also rejects this idea. Her view is that "where claims are concerned the numbers do not count. ${ }^{m 33}$ Thomson calls this theory the "High-Threshold Thesis."

Thomson's account of moral rights gives more detail than Dworkin's account of legal rights with respect to when rights must be given accord and when they permissibly may be infringed. Thus, Thomson brings us somewhat closer to our goal of understanding the relationship between rights and policy. Nevertheless, Thomson has not said enough to provide principled guidance into when Tradeoffs are permissible. Depending upon how "sufficiently much more" is ratcheted up or down, Thomson might be understood as defending a view approaching either consequentialism or deontological absolutism. But, pace Thomson, her aim was not to provide the sort of specificity necessary to answer the narrower question underlying this Comment. As she says, a general "theory of rights cannot be expected to supply a nonvague general formula by means of which it can be decided, quite generally, when it is permissible to infringe a claim." What Thomson really offers is "something more openended, a way of looking at rights. ${ }^{, 66}$

\section{THE LIMTTS OF DEONTOLOGY}

It is sometimes easy to apply deontological restrictions to actual situations. The examples philosophers and legal theorists bandy about are often straightforward. Torturing an innocent child to achieve some trivial good is obviously wrong. The easy cases found in

\footnotetext{
9s Id. at 167 n.5.
}

See id. at 167 .

${ }^{95}$ Id. at 165 . "[W] hat makes a claim infringement permissible or impermissible is an extremely complex affair, turning not only on the stringency of the claim, and the size of the increment of good to be got by infringing it, but on other things as well." Id. at 164-65.

${ }^{96}$ Id. at 33 . 
theoretic discussion are purposely designed to hone our theoretic intuitions so that we may better understand the topography of the abstract.

Only rarely is the real world so simple. Morally comprehending most actual situations requires taking account of much more. For instance, a morally complete understanding must take account of the differences in how situations are actually perceived, ${ }^{97}$ because idealized morality divorced from epistemological realities does not serve us well in practice. Further, the complex histories of the relevant characters, their reasonable expectations, the long-term ramifications of the outcome of the case under consideration, and the subtle duties owed as a result of special relationships and commitments to projects matter morally.

These limitations, however, are primarily practical. Deontology is also limited in principle. Even if deontology were ideally contextually sensitive and epistemically sound, it still would be theoretically insufficient. Deontology simply is not a comprehensive moral theory, and thus cannot exhaustively account for our moral intuitions. ${ }^{98}$ This Part is devoted to defending this claim.

${ }^{97}$ It does no good to argue that "perceptual" differences are eliminable with full factual knowledge, for two reasons. First, for all practical purposes-and morality is ultimately a practical inquiry-differences of this sort exist. Thus, a relevant moral theory must take account of them. Second, it is not obvious that all differences in perception are eliminable even in principle. For example, two atheists might take very different views on religion in society. Douglas might perceive religion as a force that generally promotes the religious to strive to lead moral (even if somewhat moralistic) lives stressing values of love, charity, and so on. Suzanna, on the other hand, might see religion primarily as an institution of repression and patriarchy, stultifying the moral insight of the members of the sect who are taught to follow blindly the moral dictates of the leadership. Arguably, facets of each position are present in religion. Perhaps these wildly divergent characterizations are possible only because the actual facts have been imperfectly and incompletely perceived. If so, neither view is accurate, and we might wonder about the accuracy of all of our beliefs. It is also possible, however, that no relevant fact has been overlooked. Rather, perhaps the value-laden types out of which our descriptions are constructed do not map neatly onto physical facts, thus making persistent contradiction at the typological level of description possible. That even sensory perception can be ambiguous bolsters the plausibility of this claim as applied to the abstract and value-laden claims of morality. See, e.g., LUDWIG WITTGENSTEIN, PHILOSOPHICAL INVESTIGATIONS 193-208 (G.E.M. Anscombe trans., 3d ed. 1968) (demonstrating the possibility of perceiving more than one physical representation in the "duck-rabbit").

${ }^{93}$ I am skeptical about whether it is possible for a single moral theory to encapsulate completely our moral understanding. That is, my moral views incline toward theoretic pluralism. Every moral theory compelling enough to have defenders purports something morally enlightening, see infra note 115 (listing alternatives), and I doubt that all these insights are theoretically reducible to a single theory. 


\section{A. Why Deontology Cannot Be Exhaustive of Morality}

The structure of deontic norms is equivalent to that of agentrelative injunctions of the form of "You must not do $X$ "' As an agentrelative restriction, the point is not that $X$ not occur, but that you, indexed to each, not do $X^{100}$ Given this structure, if rights are to have any practical meaning, the variable's referent must be given substantive content. ${ }^{101}$ Otherwise, one will not know which facts should be given accord and will not know how to act properly.

Given this structure, deontology cannot be thought plausibly to exhaust morality. The reason is that the world is virtually saturated with normativity. If deontological maxims were exhaustive of morality, each identifiable situation to which morality applies would have to be governed by a separate deontological maxim. Normativity would be replete with trumping commands, governing even the most picayune situations. This notion is implausible for at least three reasons. Such a view raises an "epistemological problem," a "conflicts problem," and an "insufficiency problem."

Take first the epistemological problem. Every view of morality must ultimately give some account of how it is that we come to know what is right. An otherwise impressive moral metaphysics is pointless if epistemologically implausible. ${ }^{109}$ With general norms, it is plausible that we may come to learn them gradually, refining our understanding through practice. Naturalistically learning through practice, however, is foreclosed to one who sees deontology as both pervasive and particularist. Almost every situation is morally different from the rest, even if only slightly so. If deontology is exhaustive of morality, there must be a separate injunction for each situation. The epistemological

s9 See supra notes 78-79 and accompanying text (noting that rights are behavioral constraints and representing their structure thusly: "If there is an $\mathrm{X}$ such that $\mathrm{C}_{\mathrm{x}, \mathrm{Y}} \mathrm{p}$, then Y ought' to accord P" (quoting THOMSON, supra note 7, at 81)).

${ }^{100}$ If this were not so, then deontology would not prohibit violating one person's right to prevent another person from violating two people's rights. See supra note 2; see also NAGEL, supra note 10, at 175-86 ("Deontological reasons have their full force against your doing something-not just against its happening.").

${ }^{101}$ See, e.g., THOMSON, supra note 7, at 37 ("Every right is a right to something ....").

${ }^{102}$ Moreover, it simply is not theoretically interesting to posit a right for every situation in which morality has import. Such a view merely enumerates and then labels our intuitions without unifying or deepening our understanding. Call this the "aesthetic problem."

${ }^{103}$ Cf. supra note 97 (asserting that perceptual differences are not eliminable, both practically and perhaps in principle, and so a relevant moral theory must account for them). 
problem is that learning an essentially infinite number of separate rules to govern our conduct is implausible.

It initially might be thought that the epistemological problem could be overcome by allowing generality within the specific norms, thus making it possible for the student of morality to learn these general principles and then derive the specific deontological prohibitions from them. The trouble with this response is that the important theoretic work is performed by the underlying principles by which the specific deontological maxims can be learned. This is problematic because theoretic entities are abstract. As such, Ockham's Razor ${ }^{104}$ and the principles of pragmatism ${ }^{105}$ dictate that we do better to recognize conceptually the general principles. There is no logical inconsistency in positing a deontological norm for every morally distinct situation. But if pervasive, deontological maxims would be superfluous. Thus, it is theoretically preferable to deny them this exclusivity. ${ }^{106}$

Suppose the epistemological problem can be skirted by allowing that some theoretically benign generality informs our moral understanding. If deontology may be exhaustive without being particularist, then a separate objection, the conflicts problem, arises. As was true of the epistemological problem, the conflicts problem arises because morality has something to say about almost everything.

Because the world is complex, if rights are general, then the evaluation of most morally interesting situations will either depend on more than one rights claim or on some other moral element, each problematic for the claim that deontology is exhaustive of morality. The reason is structural. Our moral intuitions are highly nuancedoften minor changes to a factual situation alter the normative evaluation of that situation. But since a limited number of general norms, because they are general, cannot account for this contextual sensitiv-

${ }^{104}$ Ockham's Razor is the principle enunciated by the 14th-century Franciscan philosopher William of Ockham that "what can be explained on fewer principles is explained needlessly by more." ERNEST A. MOODY, THE LOGIC OF WILLIAM OF OCKHAM 49-50 (Russell \& Russell 1965) (1935) (quoting William of Ockham). This principle is appropriate for Ockham given his essentially nominalist metaphysics-that is, his rejection of platonic universals. See id. at 46-53 (describing Ockham's views).

${ }^{105}$ These are principles-or "virtues" - that count in favor of accepting one hypothesis over another. See W.V. QUINE \& J.S. ULLIAN, THE WEB OF BELIEF $42-53$ (1970) (describing the virtues of "conservatism," "modesty," "simplicity," "generality," and "refutability").

${ }^{106}$ Any lingering dispute over this point must be resolved by answering questions about the relationship between epistemology and metaphysics. This Comment is not the place for that discussion. 
ity, some other explanation must be offered. Positing a greater number of more specific deontological norms could account for this factual sensitivity. Doing so, however, threatens to reincarnate the epistemological problem. If our norms are relatively few in number, thereby putting them within our epistemic reach, either many norms will apply to each situation to give us the contextual sensitivity that is evident, or some other principles must be at work.

If the latter is true, no more need be said to show that deontological norms do not exhaust morality. If the former is correct, because rights claims may be overridden only when substantially more good will result-Thomson's Tradeoff Idea $^{107}$-then almost every situation will involve a true conflict of rights. Determining the resolution of these rights-conflicts would require that morality be supplemented with principles other than rights. If this is correct, rights would perform relatively little theoretic work beyond triggering these principles. Whatever principles would be regularly invoked for resolving rights-conflicts would do the bulk of the work of determining right action. Such a notion does not sit well with the claim that deontology exhausts morality, for the reasons already discussed. ${ }^{108}$

Finally, there is the insufficiency problem. Deontology cannot be exhaustive of morality because deontology fails to capture all of our moral intuitions. Deontological constraints are categorical prohibitions against determinate actions. As trumps against all but the weightiest of interests, rights are relatively unwieldy tools. If a contemplated action will violate a right, then, absent extreme circumstances, it may not be taken. Much of morality, however, is not so categorical. For example, many things are morally distasteful, imprudent, or repugnant without being absolutely prohibited.

An example central to the concerns of legal theorists is negligence. As Professor Heidi Hurd has argued, negligence cannot be accounted for within deontological theories of right action. ${ }^{109}$ Judge Learned Hand's classic definition of negligence from United States $v$. Carroll Towing $\mathrm{Co}^{110}$ is that an action is negligent if and only if the burden of preventing the harm is less than the cost imposed by the harm discounted by the probability that the harm will result. Take

\footnotetext{
${ }^{107}$ See supra text accompanying notes 87-94.

${ }^{109}$ See supra text accompanying notes 10406.

${ }^{169}$ See Heidi M. Hurd, The Deontology of Negligence, 76 B.U. L. REV. 249, 262-65, 270 (1996) (concluding that "deontologists must concede that negligence cannot be construed as deontologically wrongful").

${ }^{110} 159$ F.2d 169, 173 (2d Cir. 1947) (announcing the famous $B<P L$ standard).
} 
driving as an example. Each of us morally and legally is required to drive with due care. The imposition of risk upon others inherent in driving is unjustifiable if one negligently puts others at risk. The moral requirement to act with due care, however, may require more than the efficient outcome minimally required by law. That is, Hand's legal formulation of negligence may be too weak to capture the moral notion of negligence. Neither the moral nor the legal exhortation to drive with due care, however, is so strict that it prohibits one from driving unless substantially greater good comes from driving than not driving. ${ }^{11}$ For example, there is no prohibition against pleasure-driving. If deontic norms governed negligence, this result ostensibly would be required. ${ }^{112}$ Given the prevalence of actions legitimately evaluated under a negligence standard, and deontology's inability to account for them, it becomes clear that construing rights as omnipresent is to misconstrue them. Rather, rights mark the outer boundaries of what is morally permissible.

Where deontological limits do not constrain behavior, it seems almost analytically true that, given a choice between producing some good and more good, it is better to produce more good. ${ }^{113}$ This intuition lies at the heart of consequentialism. Consequentialism proves objectionable only when it requires violating rights or otherwise treating people in deontologically objectionable ways for the sake of the greater good. Again, where these limits are not violated, there is no reason why the maximizing intuition should not be followed. ${ }^{114}$ At the very least, the burden falls on those who think otherwise to establish their case. For the purposes of this Comment, I will assume that where deontology does not apply, the normative fine-tuning of behav-

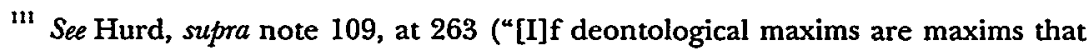
prohibit wrongdoing, and wrongdoing consists in causally-complex actions (i.e., actions that cause harm), and negligence consists, not in actions that cause harm, but in actions that risk harm, then negligence cannot constitute a violation of any deontological maxims. At most, a risk-based understanding of negligence can function as a concept of culpability.").

112 Even if one could successfully argue that pleasure-driving creates substantially greater good than the harm thus risked, if deontic norms governed negligence the permissibility of pleasure-driving would not be obvious.

${ }^{113}$ See supra note 2.

1114 See Hurd, supra note 109, at 253 ("[W] hen an action does not violate a deontological maxim, it is not deontologically wrongful. But this does not mean that it cannot still be wrongful. If it causes more bad consequences than good, it will still be wrong and a deontologist can maintain this as readily as a consequentialist."). 
ior is left to consequential calculation. ${ }^{115}$ Deontological maxims are thus best understood as defining and patrolling the borders of consequential justification. ${ }^{116}$

Given that deontological maxims do not exhaust the content of morality, it is important to know when these maxims should be given moral sway and when they should not. Because the trumping effect of rights is powerful, one is likely to make very large moral errors if rights are misapplied. The next section examines some of these limits.

\section{B. The Boundaries of Deontology}

The previous section argued that deontological norms, as a matter of principle, cannot exhaust morality. This section canvasses several well-recognized philosophical distinctions to which deontological norms sometimes do not apply. This section closely follows the analy-

${ }^{115}$ It is not as great a leap as one might think to simply take consequentialism as given. Consequentialism may be flawed as a comprehensive moral theory, as many critics would be quick to point out. For example, there are defenders of virtue ethics, see, e.g., PHILIPPA FOOT, Virtues and Vices, in VIRTUES AND VICES AND OTHER ESSAYS IN MORAI PHILOSOPHY 1, 8-14 (1978) (arguing that virtues are a corrective to human nature); ALASDAIR MACINTYRE, AFTER VIRTUE: A STUDY IN MORAL THEORY 277 (2d ed. 1984) (defending Aristotelianism), feminist ethics, see, e.g., NEL NODDINGS, CARING: A FEMININE APPROACH TO ETHICS \& MORAL EDUCATION (1984) (outlining a feminist ethic of care); Symposium on Feminism and Political Theory, 99 ETHICs 219 (1989), communitarianism, see, e.g., MiCHAEL J. SANDEL, LIBERALISM AND THE LIMITS OF JUSTICE (1982) (giving a communitarian critique of Rawlsian social contractarianism); Amy Gutmann, Communitarian Critics of Liberalism, 14 PHIL. \& PUB. AFF. 308, 320 (1985), and partialism, see, e.g., SCHEFFLER, supra note 2, at 115 (rejecting utilitarianism and consequentialism in favor of a hybrid conception or an agent-centered conception). One of the lasting strengths of consequentialism, however, is that virtually anything may be plugged into the consequentialist calculus as an intrinsic good. Although the mandate to maximize goods produces counterintuitive results when applied simplistically, consequentialism cannot be faulted for being overly narrow with respect to values. Thus, extra weight can be given to partialist concerns, acts of caring, and so on through the list of alternative values. By tweaking the nature and weight of the relevant values, a consequentialist can account for almost any moral intuition if given sufficient room to maneuver, even if in so doing the theory loses its flavor as consequentialism. Although this possibility does not assuage the global concerns of nonconsequentialists, it does mitigate the theoretic commitments made in taking consequentialism as a default position.

${ }^{316}$ This phrase is borrowed from Professor Heidi Hurd. See Hurd, supra note 109, at 254 ( $[$ TT]he principle payoff of deontological maxims is their ability to define and patrol the borders of consequential justification."). 
sis of Professor Michael Moore, ${ }^{117}$ which attempts to unify ${ }^{118}$ seven such distinctions under the criteria necessary for ascribing moral or legal culpability to wrongdoers. ${ }^{119}$ These criteria are the three conditions of culpability found in criminal law. ${ }^{120}$ Professor Moore argues that each of the distinctions discussed below tracks one of the three conditions of culpability recognized, for example, by the Model Penal Code. Of the seven distinctions Professor Moore discusses, I touch on four in this section, and reserve a fifth for more detailed analysis in the next Part since it theoretically undergirds the remainder of this Comment.

${ }^{117}$ See Michael S. Moore, Torture and the Balance of Evils, 23 ISR. L. REV. 280, 298-314 (1989) (applying these distinctions to the case of torture). Perhaps because his article discusses criminal law's balance-of-evils defense, Moore presents the distinctions as limitations on consequentialist, as opposed to deontological, reasoning. This difference, however, is purely semantic because the distinctions mark the boundary between consequentialism and deontology.

${ }^{118}$ See id. at 308-14 (discussing the commonality of the limits on consequential calculation). As Moore notes, this insight reveals a deep coherence to the intuitions of many theorists in this area, which suggests the fundamental nature of the principle that "culpability matters in determining when we may justify our acts by their good consequences." Id. at 313. Moore continues:

When a contemplated act would make us fully culpable were we to do it, we are forbidden to do it, irrespective of the good consequences we could achieve by doing it; when that act would not make us fully culpable ... then we may do it, using those same good consequences as our justification.

Id. That we lift the conditions of culpability from the criminal law is acceptable because "boldly and bluntly ... criminal law appears to be about deontological wrongs." Hurd, supra note 109, at 272. Hurd notes that this implies that the "line to be drawn between torts and crimes is a morally significant one." Id. at 271.

119 See Moore, supra note 117, at 309 ("If we reexamine the seven suggested limits on consequential calculation, we can see that they each instantiate one or another of the[] three conditions of culpability."). Moore distinguishes between wrongdoing and culpability. One does wrong to bring a state of affairs prohibited by legal or moral norms into existence. See id. at 308 . One is culpable only if one is morally or legally responsible for wrongdoing. See id.

${ }^{120}$ Under the standard analysis of culpability, an actor is culpable if she performed a voluntary act that "in fact and proximately caused the morally or legally prohibited state of affairs," with a "culpable (purposeful, knowing, reckless, negligent) state of mind." Id. at 308. This correlates to MODEL PENAL CODE $\S \S 2.01-.03$ (1985). For further discussion, see Michael S. Moore, The Moral and Metaphysical Sources of the Criminal Law, in CRIMINAL JUSTICE: NomOs XXVII, at 11 (J. Roland Pennock \& John W. Chapman eds., 1985). 


\section{The Doing/Allowing Distinction ${ }^{121}$}

This distinction has historical roots in the theoretic literature extending back at least to Philippa Foot's 1967 presentation of the issue. ${ }^{122}$ She noticed that there was a moral difference "between what one does or causes and what one merely allows. ${ }^{\text {.23 }}$ We are both morally and legally permitted to allow certain harms to befall others when acting so as to cause this same harm would be impermissible. This moral distinction helps explain why omission liability ${ }^{124}$ is treated differently than liability arising from culpably causing harm is treated. In criminal law, omission liability typically must be predicated upon an existing legal duty. ${ }^{125}$ Likewise in torts, unless specifically altered by statute, ${ }^{126}$ a legally recognized duty generally must exist before omission liability will arise. ${ }^{27}$ Thus, although one need not necessarily jump into a river to save a drowning person, either morally or legally, one may not push someone into the river if it is foreseeable that he or she will drown.

${ }^{121}$ Moore refers to this as the "allowing/acting distinction." Moore, supra note 117 , at 299.

${ }^{122}$ See Philippa Foot, The Problem of Abortion and the Doctrine of the Double Effect, 5 OXFORD REV. 5 (1967), reprinted in VIRTUES AND VICES AND OTHER ESSAYS IN MORAL PHILOSOPHY, supra note 115, at 19; see also Warren S. Quinn, Actions, Intentions, and Consequences: The Doctrine of Doing and Allowing, 98 PHIL. REV. 287, 290 (1989) (examining two of Foot's examples). It is worth noticing that the law has long recognized this distinction for its own purposes. See Buch v. Amory Mfg. Co., 44 A. 809, 811 (N.H. 1898) (denying a remedy where an eight-year-old plaintiff's hand was crushed in a machine that his 13-year-old brother, an employee, was teaching him to operate), overruled in part on other grounds by Ouellette v. Blanchard, 364 A.2d 631 (N.H. 1976). In $B u c h$, the court noted that "[t] here is a wide difference,-a broad gulf,-both in reason and in law, between causing and preventing an injury.... The duty to do no wrong is a legal duty. The duty to protect against wrong is, generally [though with exceptions] a moral obligation only...." Id.

${ }^{123}$ Foot, supra note 122, at 11, reprinted in VIRTUES AND VICES AND OTHER ESSAYS IN MORAl PHILOSOPHY, supra note 115, at 26; see also Moore, supra note 117, at 299 (quoting Foot and describing her views).

${ }^{124}$ See supra note 31 (describing several scholarly treatments of omission liability).

${ }^{125}$ See, e.g., Jones v. United States, 308 F.2d 307, 310 (D.C. Cir. 1962) (requiring a finding of a legal duty to establish omission liability in an involuntary manslaughter case).

${ }^{126}$ See, e.g., VT. STAT. ANN. tit. $12, \$ 519$ (1973) (imposing a maximum $\$ 100$ fine for failure to provide "reasonable assistance" to those "exposed to grave physical harm" and insulating the actor from civil damages absent "gross negligence").

${ }_{127}$ See generally RICHARD A. EPSTEIN, CASES AND MATERIALS ON TORTS 559-640 (6th ed. 1995) (discussing situations in which a defendant has an affirmative duty to act). 


\section{The Intending/Foreseeing Distinction}

Deontological norms constrain intentional behavior, rather than the physical occurrence of particular states of affairs. Deontic prohibitions thus operate on what "one does or chooses, either as an end or as a means, rather than something one's actions merely cause or fail to prevent but [at which] one doesn't aim.. ${ }^{128}$ A standard example is wartime bombing. It is typically thought permissible to bomb munitions factories even if it is foreseeable that neighboring civilians will be killed as a result, but it is generally thought impermissible to bomb the same number of civilians intentionally and directly as an act of psychological warfare. As Moore points out, the distinction between intending and foreseeing is very old, going back at least to Aquinas. ${ }^{129}$ The distinction underlies the doctrine of double effect, which emerged from the Catholic tradition. ${ }^{130}$

\section{The Foreseeing/Risking Distinction}

Moore identifies two different distinctions under this label. One is the distinction between "knowing to a practical certainty that someone will die... and knowing only that there is a substantial risk that this will be the case." ${ }^{\text {131 }}$ Where one merely risks harm to another, it is permissible to calculate consequentially this risk against one's "comforts" and "conveniences." 132 Deontological maxims categorically prevent risking only when it is practically certain that someone would die. The second distinction is between knowing that a particu-

${ }^{128}$ NAGEL, supra note 10 , at 179.

129 See Moore, supra note 117, at 300; see also 38 THOMAS AQUINAS, SUMMA THEOLOGIAE 38-45 (Marcus Lefébure ed. \& trans., Blackfriars 1975) (1897) (outlining the necessary conditions for action under what is now known as the doctrine of double effect).

${ }^{150}$ The doctrine of double effect holds that one may cause harm that would be deontologically prohibited if: (1) the harm is merely a foreseen but unintended consequence of the act; (2) the act itself is not morally prohibited; (3) some greater good results; and (4) the good result does not directly depend upon the bad result. See, e.g., H.L.A. HART, Intention and Punishment, in PUNISHMENT AND RESPONSIBILITY 113, 122-33 (6th ed. 1984) (giving an example in which doctors take steps to accelerate a patient's death); Warren S. Quinn, Actions, Intentions, and Consequences: The Doctrine of Double Effect, 18 PHIL. \& PUB. AFF. 334, 334 n.3 (1989) (citing 38 AQUINAS, supra note 129, at $38-45)$.

131 Moore, supra note 117 , at 301.

${ }^{132}$ See id. (citing Sanford Kadish, Respect for Life and Regard for Rights in the Criminal Law, 64 CAL. L. REV. 871, 897-98 (1976), reprinted in SANFORD KADISH, BLAME AND PUNISHMENT 109, 128-30 (1987)); see also Hurd, supra note 109 (arguing that Hand's well-known consequentialist "calculus of risk" best defines negligence). 
lar person will be harmed and knowing only that someone-although no one in particular-will be harmed. ${ }^{133}$ When a particular person will knowingly die as a result of some action, deontological norms prohibit that action. This distinction comports with the permissibility of New York City spending no more than $N$ dollars per worker on safety but being required to spend many times $N$ to save one worker who is trapped following a cave-in. ${ }^{134}$

\section{The Victim-in-Peril/Victim-Not-in-Peril Distinction}

\section{Moore states:}

[W] hen the victim of your proposed action is already in peril of suffering the harm you are contemplating inflicting, you may be justified in going ahead if the consequences ... are sufficiently good; but where the victim is not in such peril, you are absolutely forbidden to inflict such injury upon him, no matter what the consequences.

As Moore notes, a classic example associated with this distinction is the case where two shipwreck victims simultaneously come upon a plank sufficiently buoyant to save only one of them from drowning. ${ }^{136}$ Here, because each is already in danger of drowning, it is deontologically permissible for each to fend off the other in order to reach the plank lest both drown. ${ }^{137}$ If the plank were sufficient to sustain both victims, then neither would be in peril and neither could be pushed off the plank.

Another distinction, the one that will be the focus of the rest of this Comment, is what Thomson calls the distributive exemption. ${ }^{139}$ This exception to deontological norms is typically illustrated with a familiar genre of thought-experiments, and is known to legal theorists and philosophers as "the trolley problem." The discussion below will argue that all, or nearly all, legitimate government action falls

${ }^{133}$ See Moore, supra note 117, at 301 (discussing the distinction as applied to killing or torture). This is sometimes referred to as the de re/de dicto distinction.

${ }^{134}$ See supra text accompanying notes 17-18.

135 Moore, supra note 117 , at 302.

135 See id. at 303.

${ }^{137}$ See id.

iss See Judith Jarvis Thomson, The Trolley Problem, 94 YALE L.J. 1395, 1408 (1985), reprinted in RIGHTS, RESTITUTION, AND RISK, supra note 61, at 94, 108.

139 I believe that Thomson coined this phrase. See Judith Jarvis Thomson, Killing, Letting Die, and the Trolley Problem, 59 MONIST 204, 206 (1976), reprinted in RIGHTS, RESTITUTION, AND RISK, supra note 61, at 78, 81 ("I like to call this the trolley problem, in honor of Mrs. Foot's example."). 
within this exception. ${ }^{140}$ As applied to governmental action, this "exception" to deontological norms is, in fact, the rule. I argue here that, in contrast to the relevancy of deontology at the individual level, deontology is largely irrelevant for the government servant acting in her official capacities. ${ }^{141}$

\section{The TROLLEY PROBLEM}

Philippa Foot founded an entire cottage industry several decades ago by introducing her Trolley Problem. ${ }^{142}$ Thomson's presentation of the problem is particularly insightful and will be followed here. ${ }^{143}$ A condensed version of the problem can be stated thus:

Suppose that a trolley is careening out-of-control down a steep hill. Just past a near fork in the track are five people who all will be killed if the trolley continues on its present course. A passer-by observes that throwing the switch will divert the trolley down a spur track and thereby save the lives of the five people on the track. However, doing so will kill the one person who is standing on the spur.

${ }^{110}$ The argument set forth in the remainder of this Comment could also be constructed from the doctrine of double effect, see supra note 130 and accompanying text, the foreseeing/risking distinction in Moore's second sense, see supra note 133 and accompanying text, and perhaps others. That multiple routes lead to the same destination lends credence to my thesis, and also illustrates the coherence of deontological doctrine generally.

${ }^{141}$ It might be possible to extend the following analysis further. In particular, the distributive exemption to deontological maxims might swallow up the very foundation of deontology, leaving only consequentialism at the base. That is, this Comment suggests, but does not develop, an argument for rule-utilitarianism.

${ }^{142}$ See Foot, supra note 122, at 8, reprinted in VIRTUES AND VICES AND OTHER ESSAYS IN MORAL PHILOSOPHY, supra note 115, at 23 (setting forth the Trolley Problem).

${ }^{148}$ See Thomson, supra note 138, at 1395, reprinted in RIGHTS, RESTITUTION, AND RISK, supra note 61 , at 94 . It should be noted that chapter seven of Thomson's The Realm of Rights, published in 1990, see supra note 7, is also entitled "The Trolley Problem," but is markedly different. The earlier essay is a more concise and rigorous account of the problem itself. The later essay seemingly attempts to dig beneath the problem in search of a more convincing solution. Thomson's later solution has farranging consequences if true. Because the later essay commits her to more, I use Thomson's earlier exposition as a springboard. Moreover, along with at least one other reader, I am less convinced by her more recent solution. See Barbara Baum Levenbook, Defender of the Realm: Thomson on Rights, 11 LAW \& PHIL. 449, 452 (1992) (reviewing Thomson's The Realm of Rights and stating that "Thomson's new solution to the Trolley Problem represents the rejection of the intuitions that these killings are permissible. I think, however, that Thomson's earlier intuitions were right.").

${ }^{144}$ See THOMSON, supra note 7, at 176 (describing the Trolley Problem); Thomson, supra note 138, at 1395, reprinted in RIGHTS, RESTITUTION, AND RISK, supra note 61 , at 94 (same). 
Virtually everyone agrees that it is morally permissible to throw the switch to save the five, although that action would kill the one. Moreover, some people think it is morally mandatory to do so. ${ }^{145} \mathrm{Al}$ though it is not generally permissible to harm one to save others from being harmed, "other things being equal, it is not morally required of us that we let a burden descend out of the blue onto five when we can make it instead descend onto one." 146 This Comment presumes that intervention is desirable. This view is somewhat stronger than holding that intervention is merely permissible, but falls short of predicating wrongdoing of one who does not intervene.

For deontologists, this intuition is puzzling because it advocates killing one so that five might live. This seems to violate deontological constraints. For a contrast, consider Thomson's Transplant case:

Suppose that Ozzie has entered the hospital for a routine physical. There are five people in that hospital who will die unless they receive various organs. Andy needs a heart, Bert a (full) liver, Cindy a kidney, and Darla and Edith each need one lung. Assuming that it is physically possible for the hospital's star surgeon to transplant Ozzie's organs into each of these patients, may the surgeon do so against Ozzie's consent if it is assured that the operations will each be successful? ${ }^{147}$

Clearly not. On these facts it is impermissible to kill one so that five might live. Doing so violates settled categorical prohibitions against killing. The question then is: What morally distinguishes the Trolley Problem from the Transplant case?

Thomson's solution is that the "distributive exemption" from deontological norms applies to the Trolley case, but not to the Transplant case. Painting with a broad brush, she claims that the distributive exemption is "very conservative" and only "permits intervention into the world to get an object that already threatens death to ... many to instead threaten death to these few, but only by acts

14 See Thomson, supra note 138, at 1395-96, reprinted in RIGHTS, RESTITUTION, AND RISK, supra note 61 , at 9495 (noting that everyone to whom Thomson posed this hypothetical agreed that it was morally permissible to redirect the trolley). Thomson's view is that it is permissible, but not mandatory, to turn the trolley. See THOMSON, supra note 7, at 196-97 ("I stress, however, that this does not mean that Bloggs must ... turn the trolley. He may do so. But he may instead do nothing. ... [or] may instead flip a coin [to decide].").

${ }^{14}$ Thomson, supra note 138, at 1408, reprinted in RIGHTS, RESTITUTION, AND RISK, supra note 61, at 108 .

${ }^{147}$ See id. at 1396, reprinted in RIGHTS, RESTITUTION, AND RISK, supra note 61, at 95 (describing the Transplant case). For ease of exposition I will, following Thomson, often refer to these cases as the "Trolley Problem" and "Transplant," respectively. 
that are not themselves gross impingements on the few. ${ }^{148}$ These statements will be made clear below. The discussion that follows examines the Trolley Problem, and permutations thereon, in detail in hopes of understanding those elements of the problem that trigger the distributive exemption.

\section{A. Fundamentals}

It will be constructive to begin by highlighting three crucial elements of the distributive exemption. The first point relates to the exemption's scope: Although Thomson's discussion revolves around examples involving death, the distributive exemption is triggered with equal facility by other rights-based claims. For example, suppose that a thief is about to dynamite a safe containing the property of five people. Suppose further that one may intervene only by substituting a different safe that contains the property of just one person when the thief is not looking. Assuming that each person has an equal right against property theft and that all the property is of equal value, and so long as the diversion of the thief's intentions itself infringes no rights that are stringent ${ }^{149}$ relative to this case, supplanting one safe for the other seems morally permissible. This seems similar to the Trolley Problem. The thief's impending evil actions are diverted, distributing the harm across fewer people. It is implausible that rights against death and theft are amenable to the distributive exemption but other rights are not. I assume, therefore, that the distributive exemption applies to all deontological norms.

Second, the distributive exemption "says nothing at all about the source of the threat." "Whether the threat to the five is, or is caused by, a human being or anything else," the exemption applies. ${ }^{151}$ Continuing with the safe-cracking example, it makes no difference that the threat was the evil intentions of a thief instead of a trolley.

Third, in taking advantage of the distributive exemption, morality requires, ceteris paribus, that one minimize the resulting harm. I refer to this as the "lesser harm requirement." Illustratively, suppose that

${ }^{148} I d$. at 1412, reprinted in RIGHTS, RESTITUTION, AND RISK, supra note 61, at 112.

${ }^{149}$ Stringency is defined above. See supra text accompanying note 91 (noting that "one rights claim is more stringent than another if it takes more good to render its infringement permissible").

${ }^{150}$ Thomson, supra note 138, at 1413, reprinted in RIGHTS, RESTITUTION, AND RISK, supra note 61 , at 113 .

151 Id., reprinted in RIGHTS, RESTITUTION, AND RISK, supra note 61, at 113. 
the trolley is headed toward five, that one person is standing on the spur on the right, and that three people are standing on the spur on the left. If the trolley is switched, morality requires that the trolley be turned onto the right spur. Intentionally choosing to divert the trolley into the three instead of the one would violate deontological norms. The ceteris paribus clause permits us to ignore cases of mistake due to haste or emotional pressure, which seem excused, and cases introducing other morally relevant factors. ${ }^{152}$

With these foundational points made, let us return to our question: What morally distinguishes the Trolley Problem from Transplant?

\section{B. The Distributive Exemption as Advantage}

In Thomson's 1990 response to the problem, she offers two ways in which the Trolley Problem can be distinguished from Transplant. ${ }^{153}$ First, throwing the switch in the Trolley Problem merely deflects a force that is already in motion. ${ }^{154}$ In Transplant, by contrast, the surgeon creates an entirely new threat. The next section discusses this distinction. Second, in the Trolley problem, it is to the "advantage" of each person on the track that the trolley be switched; however, a similar advantage does not obtain in Transplant. I refer to this as the "advantage view."

For Thomson, "advantage" approaches, but does not quite reach, an objective theory of what is good for someone. ${ }^{155}$ Although the issue is left somewhat unresolved, ${ }^{156}$ it is clear that advantage involves more than individual desire, ${ }^{157}$ and also that it "has to do with goods

${ }^{152}$ For example, if the one were my child and the three were strangers, switching the trolley into the three probably would be morally justified. Partiality has not gone unnoticed in the philosophical literature. See, e.g., Symposium, Impartiality and Ethical Theory, 101 ETHICS 698 (1991) (presenting a broad spectrum of views on partiality). In such cases the ceteris paribus clause is not satisfied because other things are not equal.

${ }^{15 s}$ Thomson also makes a third point, that the respective histories of how the people on the track came to be there are relevant. See THOMSON, supra note 7 , at 180 (noting the difference between "thrillseekers" who have chosen to be on the tracks despite the danger and workmen assigned to repair the track). For simplicity's sake, I keep the discussion clean of this sort of complication.

154 See id. (noting that this distinction is relevant but not "crucial").

${ }^{155}$ See id. at 189-90 (noting that personal idiosyncracies may mean that what is objectively good for a particular individual may in fact be bad for her and thus not to her advantage).

${ }^{156}$ See id. at 190 (suggesting that resolution of the issue be "bypassed").

${ }^{157}$ What each individual desires as an ideal rule is that the trolley be diverted down a track on which she is not standing. 
in addition to mere survival." 158 Whatever the exact nature of Thomson's understanding of advantage, for our limited purposes, we may take it to be a mixture of subjective and objective values.

Thus understood, it is not to the advantage of the one that the trolley is turned at the time the switch is pulled. Viewed sufficiently abstractly, however, given that each person is five times as likely to be in the group of five as to be alone on the spur, agreeing to a rule that permits turning the trolley increases each person's probability of survival. ${ }^{159}$ Therefore, those affected could agree in principle to social rules based upon what is to their advantage. ${ }^{160}$

In Thomson's view, Transplant is different. It is not to the advantage of the healthy to become involuntary organ donors. Health is not a matter of pure chance. It depends at least in part upon lifestyle choices, for example, choosing to exercise and to refrain from regularly indulging in "steak, gin, and cigarettes." 161 Those who regularly exercise and practice restraint will, on average, be healthier than those who do not. Thomson's view does not seem to be that allowing organ harvesting would function as a disincentive to be healthy, thus decreasing advantage on average. Rather, Thomson believes that even if our society would accrue more advantage by allowing harvesting than by not, Transplant is still impermissible because it is not to the advantage of the healthy that their organs be harvested. ${ }^{162}$ However, because the class of healthy people is analogous to the "one" in the original Trolley Problem, Thomson must say more to distinguish these examples.

Although Thomson does not put it quite this way, one difference is that our sense of who we are as people is much more intimately connected with our health than with upon which trolley track we might happen to be standing. If health can legitimately be included as a constituent part of self-identity, it makes little sense to query what would be in one's best interest abstracted from such a defining characteristic. Analogously, Thomson notes that although it is logically

${ }^{159}$ THOMSON, supra note 7, at 195.

159 See id. at 181 (noting that the six individuals, if asked without knowing whether they would be assigned to the group of five, all would prefer that the trolley be turned upon the one).

${ }^{160}$ See id. at 183-88. Thomson gives what is essentially a social-contractarian view of how consent might be achieved, see id. at 182-84, although she takes the consent itself to be epiphenomena supervening on more important facts, see id. at 188 n.5.

161 THOMSON, supra note 7, at 184.

${ }^{169}$ See id. at 183 (noting that harvesting decreases the probability of survival for the healthy). 
possible to contemplate what might be good for oneself irrespective of one's mostly deeply held beliefs, there is little point to it. ${ }^{163}$ One's make-up as a person is defined in part by those beliefs. Were these beliefs different, one's desires and preferences would be different. ${ }^{164}$

Even if Thomson convinces us that health is partially constitutive of self-identity, this response is not without problems. In 1985, Thomson presented the following example, which I quote in full:

Consider a case-which I shall call Fat Man-in which you are standing on a footbridge over the trolley track. You can see a trolley hurtling down the track, out of control. You turn around to see where the trolley is headed, and there are five [people] on the track where it exits from under the footbridge. What to do? Being an expert on trolleys, you know of one certain way to stop an out-of-control trolley: Drop a really heavy weight in its path. But where to find one? It just so happens that standing next to you on the footbridge is a fat man, a really fat man. He is leaning over the railing, watching the trolley; all you have to do is give him a little shove, and over the railing he will go, onto the track in the path of the trolley. Would it be permissible for you to do this? Everybody to whom I have put this case says it would not be. But why? ${ }^{165}$

If Thomson's advantage view is correct, she must say that it is not to the advantage of the fat man that he be toppled. And clearly it is not. Thomson, however, cannot simply stop there. Under the advantage view, she must explain why it is not to the advantage of each of us that one be killed when the certain death to five can be avoided by killing that one. In Transplant, the answer I ascribed to her was that the killing would unequally distribute risk on a certain class of people, the healthy. That is not the case here. Perhaps only fat people will stop trolleys; but, just as plausibly, only thin people will plug leaks in dikes. Generally, there is no reason to think that any particular class will be unequally endangered if the distributive exemption is ex-

${ }^{165}$ See id. at 189-90 (discussing the case of a Christian Scientist whose deeply held religious beliefs prevent his consent to medical operations even to save his life).

${ }^{164}$ This point, if extended, gives rise to a certain degree of skepticism regarding interpersonal utility comparisons. See, e.g., Daniel M. Hausman, The Impossibility of Interpersonal Utility Comparisons, 104 MIND 473 (1995) (arguing that well-being is not best understood on a preference-satisfaction view); see also THOMAS NAGEL, What Is It Like to Be a Bat?, 83 PHIL. REV. 435 (1974), reprinted in MORTAL QUESTIONS 165 (1979) (arguing that subjective experience can never be captured by a purely objective theory of mental states). For an antiskeptical view, see Thomas M. Scanlon, The Moral Basis of Interpersonal Comparisons, in INTERPERSONAL COMPARISONS OF WELL-BEING 17 (Jon Elster \& John E. Roemer eds., 1991).

${ }^{165}$ Thomson, supra note 138, at 1409, reprinted in RIGHTS, RESTITUTION, AND RISK, supra note 61 , at 109 . 
tended to these sorts of cases. ${ }^{166}$ Thus, it is unexplained why it is not to the advantage of each to agree to permit both toppling and plugging, as well as other sacrifices of fewer for the benefit of more.

Perhaps Thomson can adequately distinguish these cases; I am not arguing that her advantage view is incorrect. Rather, the advantage view attempts to provide a very deep explanation for why we have the rights that we do. Such a project is more metaphysical than necessary for my purposes. Rights are observable on the surface, and Thomson's 1985 response to the Trolley Problem provides a descriptive explanation for them. As a descriptive account, ${ }^{167}$ the older view may not be as theoretically satisfying as the more explanatory advantage view, but it also requires fewer theoretic commitments, and is therefore more defensible.

\section{The Distributive Exemption as Deflection}

As we have seen, the distributive exemption is a conservative exception to deontological norms, permitting intervention to minimize an impending harm, whatever its source. The last section illustrated the necessity of placing limiting principles on the distributive exemption. Otherwise, the exemption would permit throwing the fat man off the footbridge into the path of the trolley. Thomson's 1985 response, a view she did not completely abandon in her 1990 response, describes a limiting principle that distinguishes the Trolley Problem from both Fat Man and Transplant. This principle holds that intervention under the distributive exemption may only be "by acts that are not themselves gross impingements on the few. That is, the intervenor must not use means that infringe [the] stringent rights of the few in order to get his distributive intention carried out."168 Cutting up Ozzie or pushing the fat man off the footbridge violates stringent

${ }^{166}$ One objection might be that, given the prevalence of racism, sexism, and the like in our society, permitting intervention on these facts will unequally endanger members of identifiable and disempowered groups. Intuitively, however, societal racism and sexism seem irrelevant to the deontological constraints against throwing the fat man off the footbridge. Moreover, this response cannot morally distinguish the Trolley Problem from Transplant.

${ }^{167}$ Thomson, too, sees her 1985 account as more descriptive than explanatory. See Thomson, supra note 138, at 1408, reprinted in RIGHTS, RESTITUTION, AND RISK, supra note 61, at 108 ("I do not find it clear why there should be an exemption for, and only for, making a burden which is descending onto five descend, instead, onto one. That there is seems to me very plausible, however.").

${ }^{163}$ Id. at 1412, reprinted in RIGHTS, RESTITUTION, AND RISK, supra note 61, at 112; see supra text accompanying note 91 (defining stringency). 
rights. Thomson claims that, in contrast, "turning the trolley onto the right-hand track is not itself an infringement of a right of anybody's, ${ }^{169}$ for the death of the one on the spur is merely incidental to the diversion of the trolley. ${ }^{170}$ If "by some miracle the trolley did not hit" the one, the "agent would do the one no wrong." who throws the trolley's switch merely deflects a threatening force that is already in motion, ${ }^{172}$ while the surgeon in Transplant and the person who pushes the fat man off the footbridge both create entirely new threats.

The defensibility of Thomson's limiting principle is not obvious. Illustratively, in an example Thomson provides, wobbling the handrail is an act that is not itself violative of any rights, but could have the incidental effect of tipping the fat man onto the tracks. ${ }^{173}$ Morality precludes wobbling the handrail in this context. Thomson counters by highlighting the fact that " $[\mathrm{g}]$ etting the trolley to threaten the fat man instead of the five requires getting him into its path." ${ }^{174}$ The fat man's death is necessary to achieve the desired benefit in a way not true of the one in the original Trolley Problem. Thus, Thomson argues, the intervention to minimize harm in Fat Man does not fall under the distributive exemption because the intervention requires "acts that are ... themselves gross impingements on the few. ${ }^{\text {175 }}$ Let us consider another case, which I will call Rock.

Suppose that the only way to stop the trolley from killing the five is to roll a large rock down the hill into the trolley's path. Suppose further that a man is napping downhill from the rock and will be crushed by the rock if it is rolled. Again, the distributive exemption permits intervention only if intervening will not itself infringe stringent rights. Rolling the rock is not intended to kill the man, nor is his death required to stop the trolley. Nevertheless, Thomson, judging by her reaction to an analogous case, thinks it plain that you may

${ }^{169}$ Thomson, supra note 138 , at 1409 , reprinted in RIGHTS, RESTITUTION, AND RISK, supra note 61 , at 109 .

${ }^{170}$ See id. at 1409-10, reprinted in RIGHTS, RESTITUTION, AND RISK, supra note 61, at $109-11$ (concluding that diverting the trolley only infringes on one's rights if doing so causes the one harm).

171 Id. at 1409, reprinted in RIGHTS, RESTITUTION, AND RISK, supra note 61, at 109.

172 See THOMSON, supra note 7, at 180 (distinguishing this case from Transplant).

173 See Thomson, supra note 138, at 1409-10, reprinted in RIGHTS, RESTITUTION, AND RISK, supra note 61 , at 109-10 (comparing the wobbling version of Fat Man to the toppling version).

17 Id. at 1410, reprinted in RIGHTS, RESTITUTION, AND RISK, supra note 61, at at 110.

${ }^{175}$ Id. at 1412, reprinted in RIGHTS, RESTITUTION, AND RISK, supra note 61, at 112 
not roll the rock. ${ }^{176}$ Thomson's intuitions will be followed here. ${ }^{177}$ Thomson must thus say more to account for the impermissibility of intervening in Rock.

One difference between the Trolley Problem and Rock is that in Rock, the intervention creates a threat that did not already exist. As Thomson says of the Trolley Problem, " $t]$ he bystander who proceeds does not merely minimize the number of deaths which get caused: He minimizes the number of deaths which get caused by something that already threatens people, and that will cause deaths whatever the bystander does." 178 The trolley already is a causal force sufficient to cause harm. In Rock, unless the intervener pushes the boulder down the hill, no harm will be causally traceable to the rock.

This analysis suggests two related facts. First, it suggests that permissible intervention is predicated on an inevitability requirement. It must be the case for one who intervenes that she diverts "something that is already a threat to more, and thus something that will do harm whatever [s] he does." ${ }^{179}$ Second, it suggests-or reminds us as the case may be-that causation matters with respect to culpability. ${ }^{180}$ Diverting an existing threat that cannot be stopped and that will inevitably cause harm arguably does not proximately cause harm. Diverting the trolley is more similar to an imperfect and incomplete stopping than it is to purposefully causing the trolley to run over the one. On the facts as imagined, we might console the passerby who pulled the switch by saying that it was not her fault, that she did not kill the

${ }^{176}$ See id. at 1407, reprinted in RIGHTS, RESTITUTION, AND RISK, supra note 61, at 107 (discussing an example in which the ceiling of a hospital room will cave in unless it is supported by a mechanism that will release toxic gasses into the next room where an immovable patient lies).

${ }^{177}$ Thomson's deontological intuitions are particularly rights-respecting, and not all deontologists may agree with her judgment on this point. I follow Thomson here because I wish to show how even an ardent deontologist can theoretically defend consequentially justified governmental policies. Such a task is easier if Thomson is mistaken at this juncture, and hence, if the argument below is successful, no harm can ensue to my thesis by taking this turn.

${ }^{178}$ Thomson, supra note 138, at 1408, reprinted in RIGHTS, RESTITUTION, AND RISK, supra note 61 , at 108.

${ }^{179}$ Id., reprinted in RIGHTS, RESTITUTION, AND RISK, supra note 61, at 108. Where harm is not inevitable, the intervenor is under an obligation not to cause harm. Theoretically, we might either say that such cases do not fall under the distributive exemption at all, or, if the exemption applies, count such cases as a particular type of application of the lesser-harm requirement.

${ }^{180}$ Legal theorists are well aware that causation is a necessary predicate of culpability. See, e.g., supra note 120 (noting that there must be both cause in fact and proximate causation before culpability attaches). 
one-the trolley did. ${ }^{181}$ A similar statement offered to assuage the guilt of one who rolled the rock would not be convincing. This response is sufficient to distinguish the Trolley Problem from Fat Man and Rock.

For our purposes, understanding the Trolley Problem is primarily a matter of understanding which criteria trigger the distributive exemption. ${ }^{182}$ Through the discussion above, we have accumulated a list of the essential elements of the distributive exemption. To summarize, we have seen that the distributive exemption applies whenever there is a threat from any source that will cause harm inevitably, irrespective of the intervention. In such a case, intervention is desirable if diverting the existing threat will result in an outcome of less harm. The distributive exemption permits such intervention only when the intervention retains the character of a diversion of an existing threat, as opposed to the creation of a new threat. Further, upon intervention, one is morally obligated to act so as to minimize harm. This then is the Trolley Problem.

Of the threats we face daily in our world, trolleys do not rank as particularly fearsome. The next Part examines whether the morally relevant elements of the distributive exemption are found in state action.

\section{THE RELATION OF THE STATE TO DEONTOLOGY}

In this Part, I argue that the criteria that trigger the distributive exemption to deontological norms are evident in society generally. This argument implies two things. First, applying the distributive exemption to society provides an alternative justification for the existence of the coercive state, both on traditional social-contractarian assumptions and as applied to a more realistic view of the modern state.

${ }^{181}$ Most morally sensitive people would feel remorse for killing the one on the spur even if they believed that pulling the switch was morally mandatory. This phenomenon is known as "agent-regret." See Bernard Williams, Moral Luck, in MORAL LUCK 35, 42-43 (Daniel Statman ed., 1993) (defining "agent-regret" as a subspecies of regret that one can feel only toward her own past causal contribution to the world, even if nonvoluntary).

${ }^{182}$ This is not to deny that a "true" explanation is possible, or even that it has not already been offered. See supra text accompanying note 167 (recounting that Thomson's advantage view might explain the Trolley Problem). However, because the distributive exemption is inherent in the structure of deontology, any deep explanation of the exemption likely would possess the theoretic resources to explain deontology generally. Defending such a view is the province of purely moral as opposed to legal philosophy, and is far beyond the scope of this Comment. 
One important practical effect is that libertarians arguing for a minimalist state may no longer base their arguments on deontological intuitions, at least not in any simple way. Second, applying the distributive exemption to the state informs our sense of the relationship between deontology and consequentialism and the justificatory role each plays in determining permissible governmental action. This application of the distributive exemption brings consequentialist reasoning to the fore of moral importance when justifying governmental action, and makes deontology largely irrelevant when crafting governmental policy. Thus, the scope of our political rights (for example, free speech or privacy) generally must be defined within a consequentialist framework. We are forced to view rights either as weighted goods to be maximized along with every other often less lofty good (such as economic benefit), or offer a rule-consequentialist account of them. A proponent of the latter approach would argue that recognizing robust rights maximizes the general welfare. ${ }^{189}$ In either case, however, which rights we have depends upon consequentialist justification. This conclusion is surprising given its derivation from deontological premises.

\section{A. The State of Nature}

Our social-political mythology ${ }^{184}$ holds that long ago, in a purely

${ }^{183}$ Thus, were consequentialism theoretically fundamental, this would not imply that rights are ineffective as trumps against governmental policy choices. Therefore, the supervention of deontology on consequentialism, to employ a physicalistic metaphor, does not bankrupt the theoretic importance of deontology. It merely renders deontology a less metaphysically deep account of moral norms.

184 The social-contractarian tradition denoted here is deeply rooted in Hobbes, see Thomas Hobbes, Leviathan (Edwin Curley ed., Hackett Publ'g Co. 1994) (1668), on whom I exegetically rely in this section. Earlier versions of social contractarianism exist:

By nature, they say, to commit injustice is a good and to suffer it is an evil, but that the excess of evil in being wronged is greater than the excess of good in doing wrong, so that when men ... taste of both, those who lack the power to avoid the one and take the other determine that it is for their profit to make a compact with one another neither to commit nor to suffer injustice, and that this is the beginning of legislation and of covenants between men....

Plato, RePUblic 358e-359a (Paul Shorey trans., Harvard Univ. Press 1930), reprinted in THE COLLECTED DIALOGUES OF PLATO 575, 606 (Edith Hamilton \& Huntington Cairns eds., 1961). 
hypothetical land, ${ }^{185}$ we lived without governing institutions. It is not simply that society lacked a government to keep evil in check. Rather, according to the myth, there was no social order of any sort: no morality, ${ }^{186}$ no normative social practices, no culture, and so on. ${ }^{187}$ This situation compelled each person to satisfy her own pleasures, without regarding the costs that might fall on others. ${ }^{188}$ Without the behavioral constraints of law, morality, culture, and the like, it was war of all against all. ${ }^{189}$ Presumably and unsurprisingly, life under these circumstances was "solitary, poor, nasty, brutish, and short." This was the Hobbesian state of nature. ${ }^{191}$

The state of nature was not a happy situation for anyone. ${ }^{192}$ The traditional social-contractarian story holds that because even the strongest are vulnerable, ${ }^{193}$ it is universally advantageous to order so-

${ }^{185}$ See HOBBES, supra note 184, at 77 ("It may peradventure be thought, there was never such a time nor condition of war as this; and I believe it was never generally so, over all the world.").

${ }^{186}$ See id. at 78 ("To this war of every man against every man, this also is consequent: that nothing can be unjust. The notions of right and wrong, justice and injustice, have there no place." (footnote omitted)).

${ }^{187}$ In the state of nature,

there is no place for industry, because the fruit thereof is uncertain, and consequently, no culture of the earth, no navigation, nor use of the commodities that may be imported by sea, no commodious building, no instruments of moving and removing such things as require much force, no knowledge of the face of the earth, no account of time, no arts, no letters, no society, and which is worst of all, continual fear and danger of violent death.

Id. at 76 .

${ }^{188}$ Hobbes held that diffidence, which arises naturally, see id. at 75 , leads to quarrels into which each is compelled for the sake of safety, see id. at 76.

${ }^{189}$ See id. at 76 (noting that "during the time men live without a common power to keep them all in awe, they are in that condition which is called war, and such a war as is of every man against every man").

${ }^{190} I d$.

191 Not all versions of social contractarianism paint the prepolitical world as bleakly as does Hobbes. The element common to all versions of social contractarianism (of which I am aware) is the presumption of self-interested and rational contractors. See, e.g., DAVID GAUTHIER, MORALS BY AGREEMENT (1986) (giving detailed development to social contractarianism assuming rational and self-interested agents). John Rawls is the most famous modern social-contractarian, although he calls his view "Kantian constructivism." See RAWLS, supra note 45, at 12, 142-50 (discussing the presumed rationality of the parties behind the "veil of ignorance").

${ }^{192}$ See HOBBES, supra note 184, at 75 ("Again, men have no pleasure, but on the contrary a great deal of grief, in keeping company where there is no power able to over-awe them all.").

193 See id. at 74 (noting that "the weakest has strength enough to kill the strongest, either by secret machination, or by confederacy with others that are in the same danger with himself"). 
ciety legally, socially, and morally. ${ }^{194}$ In an ordered society, each agrees to constrain her behavior within certain parameters and to accept punishment for noncompliance, in exchange for the consideration that others do likewise. ${ }^{195}$ Enforcing this social agreement requires a sovereign more powerful than any confederate segment of society. Thus arose the sovereign state. ${ }^{196}$

Significant worries exist about the validity of the socialcontractarian justification for coercive government. ${ }^{197}$ For example, few people actually consent to governance by our existing institutions. ${ }^{198}$ Actual consent is limited to tacit consent. Tacit consent, however, forms a weak moral foundation for something as monumental as society's governing institutions, particularly when the state coercively prevents individuals from opting out of state governance. Because pure actual consent is nonexistent, and tacit consent is problematic, social contractarians often attach theoretic weight to some form of hypothetical or idealized consent. ${ }^{199}$ It is unclear, however, why the consent of hypothetical or idealized individuals, divorced from their gender, religion, culture, and personal projects ${ }^{200}-$

194 These social constraints all depend in part upon agreements of various types. For Hobbes, absent the coercive power of a sovereign, there was little hope for such covenants. See id. at 106 (stating that "covenants without the sword are but words, and of no strength to secure a man at all"). But see Edwin Curley, Introduction to id. at viii, xxvii-xxviii (arguing that some agreement might still arise).

195 See HOBBES, supra note 184, at 109 (stating the hypothetical agreement: "I authorise and give up my right of governing myself to this man, or to this assembly of men, on this condition, that thou give up thy right to him, and authorize all his actions in like manner" (emphasis omitted)).

${ }^{196}$ See id. (noting that " $[t]$ he only way to... defend [against] ... the injuries of one another, and thereby to secure them in such sort as ... they may nourish themselves and live contentedly, is to confer all their power and strength upon one man, or upon one assembly of men").

${ }^{197}$ At least this holds true for deontologists. Because the benefits of society outweigh its costs, consequentialists are not overly troubled by coercive governments.

${ }_{198}$ Doing so would require something akin to each person voluntarily signing a binding contract upon attaining an age of legal maturity.

199 Gauthier and Rawls, in addition to Hobbes, both have gone in this direction in their work. See GAUTHIER, supra note 191, at 9 (providing an overview and stating that the moral principles of "morals by agreement" are "introduced as the objects of fully voluntary ex ante agreement among rational persons. Such agreement is hypothetical, in supposing a pre-moral context for the adoption of moral rules and practices."); RAwLS, supra note 45 , at $12,136-42$ (hypothetically stripping each person of knowledge of contingent facts about herself and then obtaining consensus behind this "veil of ignorance").

${ }^{200}$ This describes Rawlsian individuals behind the veil of ignorance. See RAWLS, supra note 45, at 12 (stating that behind the veil of ignorance, "no one knows his place in society, his class position or social status, nor does any one know his fortune in the 
that is, divorced from $u s-$ can have significant moral bearing in justifying actual social institutions. ${ }^{201}$

I question whether the social-contractarian justification for the state is ultimately sound, but this Comment does not attempt to resolve the problems facing contractarianism. ${ }^{202}$ Rather, in this section I put the presumptions of the social-contractarian story to a new use. I argue that the unfettered human passions ${ }^{203}$ evident in the state of nature are analogous to the trolley of Thomson's example. Less metaphorically, I claim that the assumptions of the social-contractarian story satisfy the criteria that trigger the distributive exemption from deontological norms.

The distributive exemption is triggered by a threat from any source that inevitably (that is, irrespective of the intervention) will cause harm. ${ }^{204}$ In the state of nature, each person had "no more to fear than another man's single power" to restrain him from simply taking what he wanted. ${ }^{205}$ Since each person's "single power" was not an effective deterrent, all were threatened by the unfettered desires of the rest. As Hobbes illustrated it, "if one plant, sow, build, or possess a convenient seat, others may probably be expected to come prepared with forces united, to dispossess and deprive him, not only of the fruit of his labor, but also of his life or liberty." ${ }^{206}$ Human passions ran unchecked and out of control.

Against this backdrop, introducing a sovereign is analogous to introducing a passerby. Social contractarians presume that people are rational self-maximizers. ${ }^{207}$ As such, their behavior can be directed

distribution of natural assets and abilities, his intelligence, strength, and the like," nor do "the parties... know their conceptions of the good or their special psychological propensities").

${ }_{201}$ See, e.g., SANDEL, supra note 115 (giving a communitarian critique of Rawlsianstyled social contractarianism). For a general history and critique of contractarianism, See MiCHAEL LESSNOFF, SOCIAL CONTRACT (1986).

${ }^{202}$ Nor am I attempting to present a comprehensive justification of the state, fit for every purpose. The analysis below is admittedly too ungainly for that.

${ }_{203}^{20}$ I use "unfettered human passions" fairly literally. Unfettered human passions are human desires unrestrained by law or morality that motivate those who possess them to act in ways not conducive to civil society.

${ }^{204}$ See supra text accompanying note 179.

${ }^{205}$ HOBBES, supra note 184 , at 75.

${ }^{205} I d$.

207 See, e.g., RAWLS, supra note 45, at $142-50$ ("I have assumed throughout that the persons in the original position are rational."); see also id. at 62 (arguing, in defining injustice, that "[a]s a first step, suppose that the basic structure of society distributes certain primary goods, that is, things that every rational man is presumed to want"). 
through incentives and disincentives. ${ }^{208}$ Punishing wrongdoing and rewarding laudatory acts induce most people to act in socially beneficial ways. By creating a system of social incentives-for example, by legislating criminal statutes or announcing common-law civil causes of action-the state intervenes in the state of nature. Although this intervention is more complex ${ }^{209}$ than merely throwing the switch on a trolley track, ${ }^{210}$ the creation of social incentives is an intervention nonetheless. The sovereign's system of threats of punishment and promises of reward functions as a barrier and channels human desire down more socially constructive paths.

The state of nature also satisfies the inevitability requirement. Without intervention, the state of nature harms all; intervention harms at least two classes of people. First, intervention harms those who cannot abide by the constraints of the rules, notably the people subject to, inter alia, civil or criminal sanctions. Second, intervention harms those who are mistakenly identified with the class just mentioned, such as innocent people who are falsely convicted. ${ }^{211}$ In either case, the intentional actions of the state foreseeably harm some people in order to benefit a greater number of others. ${ }^{212}$ It would be uto-

${ }^{203}$ This fundamental belief about human psychology is central to many disciplines, such as psychology, economics, criminal law, and the like. See, e.g., Richard A. Posner, An Economic Theory of the Criminal Law, 85 ColuM. L. REv. 1193, 1194 (1985) (asserting that "the substantive doctrines of the criminal law ... can be given an economic meaning and can indeed be shown to promote efficiency"); see also 1 JEREMY BENTHAM, Principles of Penal Law, in THE WORKS OF JEREMY BENTHAM 365, 396, 402 (John Bowring ed., Russell \& Russell 1962) (1838-1843) ("Pain and pleasure are the great springs of human action. When a man perceives or supposes pain to be the consequence of an act, he is acted upon in such a manner as tends, with a certain force, to withdraw him, as it were, from the commission of that act.... In matters of importance every one calculates. Each individual calculates with more or less correctness, according to the degrees of his information, and the power of the motives which actuate him; but all calculate.").

${ }^{209}$ It would be a large task even to count the library of volumes of the regulatory, statutory, and judge-made law at the federal and state levels. Federal law alone fills hundreds of volumes.

${ }^{210}$ The intervention also possesses a temporal extensiveness absent in throwing a switch. The evolving law of the United States has deep historical roots. See, e.g., CORNELIUS J. MOYNIHAN, INTRODUCTION TO THE LAW OF REAL PROPERTY 1 (2d ed. 1988) (discussing very old property rules, and noting that "[a] thorough understanding of the modern land law is impossible without a knowledge of its historical background. That law has been a millennium in the making.").

${ }^{211}$ See supra notes 18-20 and accompanying text (noting that increased lawenforcement efforts will result in the punishment of some innocent people).

${ }^{212}$ This fact highlights the need for a deontologically acceptable justification for the existence of the state. Some might argue that none are harmed by the state's creation of social incentives. Such people might claim that the anarchy of the state of na- 
pian naĩveté to believe that social order is possible without harms of this type. ${ }^{213}$

The above seems an apropos extension of the Trolley metaphor. If the analogy bears weight, it provides an alternative justification for the existence of coercive government. Some libertarian scholars have argued that a minimal state "is the most extensive state that can be justified. Any state more extensive violates people's rights. ${ }^{214}$ Robert Nozick's argument, quoted here, depends upon the idea that " $[t]$ here is no central distribution, no person or group entitled to control all the resources, jointly deciding how they are to be doled out. ${ }^{215}$ The distributive exemption, however, permits even a passerby to intervene; no privileged moral status is necessary. ${ }^{216}$ If the distributive exemption applies to the state, the state is justified in acting for the general welfare, within the principled limits of the distributive exemption, even if doing so harms some people. Rights-based arguments no longer will offer principled objections to the existence of a coercive state on this basis. Instead, deontological arguments will have to be offered only within the framework of recognized political rights.

There are several possible concerns that should be addressed before we take this analogy as instructive. When the Trolley Problem was outlined above, we saw that it did not matter whence the threat arose. ${ }^{217}$ The threat of unfettered human passions in the state of na-

ture is worse for each and every person than an ordered state. This accords with the justice of Rawls's two principles of justice. See RAwLS, supra note 45, at 60 (requiring that "each person is to have an equal right to the most extensive basic liberty compatible with a similar liberty for others," and that "social and economic inequalities are to be arranged so that they are both (a) reasonably expected to be to everyone's advantage, and (b) attached to positions and offices open to all"). However, those people who are relatively strong in the state of nature are not necessarily better off in ordered society, as they are only entitled to the fruits of their own labor. Moreover, the innocent person on death row is not likely to be convinced that he is better off than if he were free in an anarchic society. See supra note 19 (introducing the example of innocent people on death row).

${ }^{213}$ More accurately, any realistic hope of society without harms of this sort does not seem desirable. The social order of Aldous Huxley's Brave New World is arguably possible, but is to be avoided nonetheless. See ALDOUS HUXLEY, BRAVE NEW WORID (1932).

${ }^{214}$ NozICK, supra note 4, at 149.

${ }^{213} \mathrm{Id}$.

${ }^{216}$ As Nozick rightly notes, however, certain other conditions might be necessary for the existence of the state, such as the possession of a monopoly of force within a geographic area, see id. at 23-24, or the recognition by the citizens of the legitimacy of the state, see id. at 337 n.15 (citing H.L.A. HART, THE CONCEPT OF LAW 113-20 (1961)).

${ }^{217}$ See supra text accompanying notes 149-51 (demonstrating that the distributive exemption could be triggered by intentional actions). 
ture, however, is abstract and widely distributed throughout society. This is a significant extension of the metaphor. Nevertheless, as before, the source of the threat proves irrelevant. Consider the following cases. Suppose that a trolley is heading toward five people from the east, and a rockslide is heading toward the same five from the north. There is no reason to suppose that two threats may not be diverted as justifiably as one. More aptly, consider just a rockslide heading toward a crowded village located at the bottom of a steep hill. The rockslide may be conceptualized as millions of individual stones, each bouncing in its own erratic path, none essentially related to the rest. Each stone may be large enough to do harm individually and would constitute a threat to someone or something if unchecked. That there are now many such threats occurring at once provides no reason to think that the rocks may not be diverted en masse. ${ }^{218} \mathrm{Ab}$ sent any reason to think otherwise, we may suppose that the distributive exemption can be triggered by diffuse threats. ${ }^{219}$

There is, however, a more serious concern. The distributive exemption only justifies the diversion of existing threats; it does not permit the creation of new ones. ${ }^{220}$ It might be thought that to punish rule-violators is to create new threats. Before addressing this objection, it should be remembered that the reason that the Trolley Problem is a problem is that some are nonculpably, yet knowingly, harmed. The one on the spur into which the trolley is diverted faces a threat she otherwise would not have faced. So we must mark our distinctions carefully here. Consider first a contrasting case. Suppose the sovereign, in an effort to gain widespread compliance with societal rules, randomly executes a citizen, falsely publicizing that the citizen had broken the rules. This execution has the character of a new

${ }^{218}$ If one is tempted to think that a rockslide is a unique individual because it is a natural kind, we might instead alter the example so that the threat arose from objects of many types flying from all angles purely chaotically and at temporally irregular intervals. This stipulation does not diminish the permissibility of Trolley-style diversions, and removes any nonvacuous claim that such a threat necessarily be reified singularly. One still not convinced will also be disposed to see unfettered human passions as a single threat, admitting diversion as such.

${ }_{219}$ It might be objected that if pooling threats in this way is permissible in principle, then, taken to the extreme, every possible negative outcome might be conceived as part of a single threat. If so, the lesser-harm requirement might be thought to require full-blown consequentialism. This worry is unfounded. Even allowing such an extreme pooling of threats, permissible intervention under the distributive exemption must still be diversionary. True consequentialism requires more.

${ }_{220}$ See supra note 179 and accompanying text (noting that when harm is not inevitable, the intervenor is under obligation not to cause any harm whatsoever). 
threat. Although this person is sacrificed on account of the passions of the masses, there is no real sense in which those passions have been diverted so as to cause the harm to the one executed. The sovereign is proximately causally responsible for the harm done.

Now suppose instead that the sovereign publicly promulgates rules of behavior and then threatens and effects punishment for noncompliance with these rules. Here, the system of rules and punishments functions as a barrier to specified forms of behavior. The system serves its prescriptive and proscriptive functions even if no one violates the rules. Society is made better off even if-moreover, especially if-all were to abide by the system of rules. Thus, so long as the state acts systematically, that is, so long as the rule of law obtains, punishing rule-violators is not akin to sacrificing one for the sake of others. In part, this is because every systemically endorsed instance of punishment arises in response to akratic action. ${ }^{221}$ That this is so can be derived from two implications of the somewhat unrealistic socialcontractarian presumption of general rationality. First, the presumption implies that the sovereign's system of social incentives and disincentives is structured so that a person expects to be worse off if she breaks the rules. It usually would not be rational for the sovereign to adopt rules that lacked deterrent force. ${ }^{222}$ Second, where a person expects to be worse off if she breaks the rules, the social-contractarian presumption of rationality implies that the person will be deterred, except in cases of weakness of the will. ${ }^{223}$ Importantly, however, cases

${ }^{221}$ Akrasia is the phenomenon of believing that one ought or wants to do one thing, yet is disposed to do another. Toning down the philosophic jargon, it is weakness of the will. See, e.g., ALFRED R. MELE, IRRATIONALITY 172-80 (1987) (containing a useful bibliography); Donald Davidson, How Is Weakness of the Will Possible?, in MORAL CONCEPTS 93 (Joel Feinberg ed., 1970) (discussing weakness of the will generally).

${ }^{222}$ The story is more complicated than I suggest. It might be socially beneficial to have rules that only a subset of the citizens would follow. For example, efficiency might be maximized by allowing some sheep owners, but not all, to graze their sheep in the commons. If so, the "tragedy of the commons" might be solved by adopting, but not vigourously enforcing, a rule prohibiting grazing in the commons. See Garrett Hardin, The Tragedy of the Commons, 162 SCIENCE 1243, 1244 (1968) (introducing the term and arguing that, in a world of limited resources, "[e]ach man is locked into a system that compels him to increase his herd without limit"). Thus, only the less risk averse would brave grazing. However, I will ignore this complication here. Although a lower level of compliance is sometimes beneficial to society, only those violations of the rules that exceed the optimum level of compliance will constitute a threat to society. The distributive exemption is just as easily triggered by excessive rule-violations.

${ }_{223}$ Because people are to some degree irrational, it is inaccurate to claim that all antisocial behavior results from weakness of the will. This is a problem that infects not just this Comment, but all theories presuming general rationality, including social contractarianism, economics, game theory, and others. Fortunately, this inaccuracy 
of weakness of the will are just those cases in which passions are unfettered; and unfettered passions are the initial impetus for the sovereign's intervention. The sovereign's intervention does not have the character of a threat arising from an independent source; it merely promulgates a system of behavioral barriers, into which crash those unfortunately lacking in self-restraint. Whether the sovereign intervenes or not, it is insufficiently fettered human passion that causes the harm. Enforcing a system of norms designed to further the general welfare is permitted by the distributive exemption; intentionally executing an innocent person, even if similarly seeking to further the general welfare, is not.

These views comport well with the philosophy of Lon Fuller. ${ }^{224}$ Fuller believed that law's "blood cousin" was the "morality of duty." The morality of duty "lays down the basic rules without which an ordered society is impossible .... [I]t condemns [citizens] for failing to respect the basic requirement of social living. ${ }^{226}$ This deontological moral floor, for Fuller, bears "direct relevance" on which legal norms should be crafted. ${ }^{227}$ The nature of law on Fuller's account is thus similar to the view of law articulated in this section of this Comment. ${ }^{228}$ Fuller also believed that legal requirements must be performable by law's subjects. Both Fuller's minimum criteria for the existence of a legitimate legal system (the "inner morality" of the law)

does not damage the argument of this Comment. Whatever psychological states or processes underlie antisocial behavior, in such cases it is that state or process which constitutes the underlying threat triggering the distributive exemption. The argument is simplified by assuming rationality, and introduces no error.

${ }^{224}$ See generally LON L. FULLER, THE MORALITY OF LAW (rev. ed. 1969).

295 Id. at 9.

${ }^{226} I d$. at $5-6$

${ }^{227}$ See id. at 9 . Fuller recognized, however, that law legitimately did more than set the minimum conditions for social life. See id. at 12-13 (disputing the notion that the morality of aspiration "is a matter between a man and himself"). The "morality of aspiration," see id. at 5,-the morality on which a more expansive legal framework is based-cannot legislate the "life of reason." See id. at 9 (noting that "there is no way open to us by which we can compel a man to live the life of reason. We can only seek to exclude from his life the grosser and more obvious manifestations of chance and irrationality."). One reason that legislation should not attempt to recreate morality in law is that, for Fuller, the very legitimacy of a legal system depends upon its "workability." See id. ("For workable standards of judgment the law must turn to ... the morality of duty."). Another reason is that rewarding "aspirant" behavior is ultimately subjective, and not well-suited to the fine-grained distinctions of law. See id. at 30-32 (noting that "the closer a man comes to the highest reaches of human achievement, the less competent are others to appraise his performancen).

${ }^{228}$ See supra note 210 and accompanying text. 
and his aspirational values of the legal system ${ }^{229}$ reflect this requirement. The "inner morality of the law" consists, for Fuller, of eight demands. ${ }^{230}$ For example, Fuller requires that law not be made on an ad hoc basis, that it not be contradictory, and that legal rules be understandable. $^{231}$ For Fuller, the inner morality of the law is not "something added to, or imposed on, the power of the law, but is an essential condition of that power itself." ${ }^{232}$ I concur. Only if Fuller's criteria are met can it rightly be said that violations of legal rules, conceived here as a system of incentives and disincentives, result from unfettered human passions.

The above discussion demonstrates that the central elements of the distributive exemption justify governmental intervention to move society from the state of nature toward social order. State intervention is desirable because it diverts the inevitable threat caused by unfettered human passions. The distributive exemption permits the imposition of social costs on a few to benefit the majority, so long as the costs are imposed in a way that satisfies the requirements of the exemption.

One of these requirements is the lesser-harm requirement. ${ }^{233}$ The lesser harm requirement demands, ceteris paribus, that one diverting an existing threat under the distributive exemption act so as to minimize the harm resulting from the intervention. In other words, the intervenor must act in a consequentially justified manner. Under the simple facts of the Trolley Problem, the lesser-harm requirement is obviously valid. $^{234}$ As will be shown here, this limiting principle is almost as clearly valid when applied to the State's more complex intervention.

In the Trolley Problem, the diversion is effected merely by tugging on a switch. The possible costs to the switch puller, and complications with respect to the parties affected, are factored out of the example by its simplicity. Creating rules of behavior for society is

${ }^{229}$ Fuller's aspirational values correspond to his minimum criteria. See FULLER, supra note 224, at 41 . This Comment does not discuss them.

${ }^{250}$ See id. at 46-91 (discussing each of these demands).

${ }^{231}$ See id. at 39 . In addition, Fuller required that law be adequately publicized, not be abusively retroactive, not be beyond the power of the affected party to perform, not be changed so frequently that subjects cannot orient their behavior by the rules, and not be administered incongruently with the law's publicized content. See id.

282 Id. at 155.

23s See supra text accompanying note 152.

${ }^{234}$ This is why the lesser-harm requirement, see supra text accompanying note 152 , though important, was introduced with little discussion or defense. 
different than pulling a switch. ${ }^{235}$ Nevertheless, the lesser-harm requirement still holds in the case of state action. With respect to costs on the intervenor, the state is not an individual actor who is protected from the sometimes excessive intrusions of consequentialism by values of autonomy and the like. ${ }^{236}$ The state exists solely for our benefit. Thus, insofar as costs affect only the state, they may be safely ignored. Moreover, as a general matter, any costs to the state are costs to its citizens. For example, the financial cost of governmental programs is passed directly to the members of the state in the form of taxes. Because the members of the state are the beneficiaries of the consequentialist calculations, the calculation of what constitutes lesser harm already accounts for these costs. The costs to the state, therefore, do not constitute a compelling objection to the application of the lesser-harm requirement to governmental action.

The other potential complication mentioned above is that the complexities of the consequences imposed on those potentially harmed by the diverted threat might alter the applicability of the lesser-harm requirement. It is difficult to understand what motivates this worry. However complex the consequences of state action, and whatever the values that color the judgment as to what constitutes a benefit or cost, so long as the consequences retain their nature as consequences, the analysis should not change. Although calculating optimal outcomes in complicated cases naturally involves some uncertainty, this is not a deep theoretic problem undermining the applicability of the lesser-harm requirement. ${ }^{237}$ Thus, neither the complexity

${ }^{235}$ Shelly Kagan cautions against overlooking the importance of the "ubiquity thesis" and the "additive assumption." See Shelly Kagan, The Additive Fallacy, 99 ETHICs 5, 12-18 (1988) (describing these concepts). Kagan nevertheless concludes that if a factor is morally relevant in one context, one can presume that it will be morally relevant in another. See id. at 28-31 ("Even without the additive assumption, a demonstration that a factor does make a difference in one case may still create a presumption that it does so in other cases as well.").

${ }^{236}$ See GEOFFREY SCARRE, UTILITARIANISM 182-94 (1996) (discussing arguments that consequentialism requires too much of the individual). But see SHELLY KAGAN, THE LIMTS OF MORALITY (1989) (defending a consequentialist morality that requires much of the individual).

${ }^{237}$ A deeper theoretic problem arises for the lesser-harm requirement if values, which determine what constitutes a beneficial or detrimental outcome, are incommensurable. See generally JOSEPH RAZ, THE MORALITY OF FREEDOM 321-66 (1986) (arguing for incommensurability as a refutation of utilitarianism); Cass R. Sunstein, Incommensurability and Valuation in Law, 92 MICH. L. REV. 779 (1994) (arguing for incommensurability among legally recognized values); Symposium, Law and Incommensurability, 146 U. PA. L. REV. (forthcoming June 1998). If values are incommensurable, there probably is no sense in which there is a "least" amount of harm. Calculating 
of the intervention nor the complexity of the consequences seems sufficient to undermine the applicability of the lesser-harm requirement to state action. Absent a reason to think otherwise, we should accept that the lesser-harm requirement is not diminished in the face of complexity, although discerning what it requires will obviously be more difficult.

If the distributive exemption applies to governmental efforts to bring civility to society, the implications are far-reaching. The lesserharm requirement mandates that a person act in a consequentially justified manner when otherwise legitimately intervening. Although built on deontological premises, the argument implies that it is consequentialism, not deontology, that ultimately determines proper state action. Deontology plays only a limited role. Any state action that satisfies the constraints of the distributive exemption must be justified consequentially. Before more fully explaining this point, it is important to consider a more fundamental objection.

The social-contractarian assumption, upon which this Part is predicated, is that the Hobbesian state of nature always lies in the background in those areas where the state does not intervene. This assumption is an appropriate way of explaining how society might plausibly have evolved out of the political primordial chaos. What was once a rather simple institution, protecting citizens from the state of nature, however, no longer exists in the developed world. Government has evolved. Finding the war of all against all in the absence of state action is no longer typical. ${ }^{238}$ Rather, where the coercive constraints of the state are absent, we have other institutions that structure collective action in ways that accrue to the benefit of all. In particular, there are social custom and morality. ${ }^{239}$

what constitutes lesser harm would presumably involve balancing interests of various sorts to achieve an acceptably low level of harm. This is little more than supposition, however. Adequately addressing this issue is beyond the scope of this Comment.

${ }^{239}$ The reemergence of something akin to the state of nature is certainly possible when government dissolves altogether, as exemplified by the tragedy in the former Yugoslavia. See SUSAN L. WOODWARD, Balkan TragedY: ChaOS and Dissolution AFTER THE COLD WAR $114-45$ (1995) (describing the interruption of democratization as a critical factor in the dissolution of the former Yugoslavia).

${ }^{239}$ See HART, supra note 216, at 165 (noting that systems of legal rules often are "set apart from other rules, which continue to exist side by side with those officially recognized.... [I]n all communities which reach this stage, there are many types of social rule and standard lying outside the legal system; only some of these are usually thought and spoken of as moral ...."). See generallyid. at 163-80 (discussing features of morality and social rules that distinguish them from legal rules). 
This development is important. The inevitable threat that triggered our application of the distributive exemption to the state was unfettered human self-maximizing passion. The point here is not that this threat no longer exists. Every other headline reminds us that it does. Less glibly, it is undeniable that selfish preferences quite often threaten many. It is no longer accurate, however, to tell a political story of state action that justifies every piece of legislation and every regulation as a protection of the majority from the chaos of the Hobbesian state of nature. The nature of the threat has changed.

\section{B. The Modern State}

The modern state is a large and very complex institution that impacts almost every area of our lives. ${ }^{240}$ The government has significant control over pollution levels in various geographical areas, ${ }^{241}$ the riskexposure that national banks are permitted to carry, ${ }^{242}$ the standards that consumer goods must meet, ${ }^{248}$ who may be married, ${ }^{244}$ when one loses the right to keep one's children, ${ }^{245}$ how long one's education will $\mathrm{be}^{246}$ the minimum number of hours educational television stations

${ }^{240}$ For purposes of this Comment, I treat all government as a monolithic entity, not even recognizing the distinctions inherent in federalism. Nothing theoretically interesting hangs on this simplification.

${ }^{241}$ See, e.g., 40 C.F.R. pt. 81 (1996) (outlining the Environmental Protection Agency's air quality geographical designations and classifications for various pollutants).

${ }^{242}$ See, e.g., 12 C.F.R. pt. 3 app. A (1997) (stating that the Office of the Comptroller of the Currency is to evaluate the adequacy of capital maintained by each national bank measured against the bank's exposure to risk).

${ }^{243}$ See, e.g., 16 id. $\$ 1500.18$ (a) (9) (banning any toy or other article intended for use by children under three years of age that presents a choking, aspiration, or ingestion hazard because of small parts, under the authority of the Consumer Product Safety Commission).

${ }^{244}$ See, e.g., Defense of Marriage Act, Pub. L. No. 104-199, 110 Stat. 2419 (codified at 28 U.S.C.A. $\$ 1738 \mathrm{C}$ (West Supp. 1997) (giving each state the right to deny full faith and credit to same-sex marriages recognized by other states), and at 1 U.S.C.A. $\$ 7$ (defining "marriage" traditionally for federal interpretive purposes)).

${ }^{245}$ See, e.g., 23 PA. CONS. STAT. $\$ 2511$ (1997) (stating the grounds for involuntary termination of parental rights).

${ }^{246}$ See, e.g., 34 C.F.R. $\$ 668.3$ (a) (1996) (allowing all institutions that provide at least a two-year educational program for which the institution awards an associate or baccalaureate degree to request the Secretary of the Department of Education to reduce the minimum period of instructional time of the academic year's programs to no less than twenty-six weeks). 
must program, ${ }^{247}$ exactly what information must be on food labels, ${ }^{248}$ and so on. Indeed, one is hardpressed to find any significant area of life in which the state has only negligible effect.

Effecting public good, assuming it is a good, involves costs of various types. Most obviously, there are direct costs. For example, providing social goods requires finances, which are collected through coercive taxation, which harms those taxed. ${ }^{249}$ The effects of tort litigation might also be understood as a direct harm threatened by government intervention. ${ }^{250}$ There are also indirect costs, ancillary to governmental attempts to benefit society. For example, the commonlaw remedy for wrongful discharge prevents employers from unjustifiably terminating an employee. ${ }^{251}$ Effecting this social good, however, creates transaction costs that are often enormous relative to any benefit achieved. ${ }^{252}$ Further, the administrative state imposes costs in many ways. Although there has been a noticeable move toward deregulation since the late 1970 s and early $1980 \mathrm{~s}^{253}$ the administrative

247 See, e.g., 47 C.F.R. $\$ 73.671$ (1997) (requiring each educational television broadcast station licensee to broadcast at least three hours per week of programming designed to promote the educational needs of children 16 years of age or younger, under the authority of the Federal Communications Commission).

${ }^{243}$ See, e.g., 9 id. $\$ 317.309$ (detailing the Department of Agriculture's nutrition labeling requirements).

${ }^{249}$ Coercively taking money from someone is undeniably a harm, whoever does the taking. However, this is not to say that it is a wrong. Part of the point of this Comment is to show why harms such as these are not wrongs. But see NOZICK, supra note 4 , at 169-74 (arguing that taxation is immoral and akin to forced labor).

${ }^{20}$ See, e.g., STEPHEN D. Sugarman, DoIng Away With Personal InJuRY Law 35-39 (1989) (arguing that personal injury law, by following the "compensation goal," undercompensates some plaintiffs while, "compared with how our society compensates accident victims through other modern arrangements ... pays accident victims excessively for their pain and suffering"). See generally GUIDO CALABRESI, THE COSTS OF ACCIDENTS (1970) (discussing various approaches for achieving the goals of accident law and the social consequences of each).

251 To clarify, the intervention is the legal provision of this remedy, not the remedy as applied in a particular case.

${ }^{22}$ Hence the widespread use of arbitration in labor disputes. In the median wrongful discharge tort case, "more than $\$ 160,000$ may be spent to transfer less than $\$ 74,500$ of compensation to a wronged employee." Clyde Summers, Effective Remedies for Employment Rights, 141 U. PA. L. REV. 457, 469 (1992) (stating that " $[t$ ] his is scarcely a legal remedy process but rather a redistribution device which enriches lawyers at the expense of both the employer and the employee"). That this is even plausibly justifiable relies on notions of corrective justice, or perhaps on the externalized economic benefits that result from the disincentives on employers who otherwise would wrongfully discharge employees.

${ }^{233}$ See, e.g., PETER H. Schuck, Foundations of AdMiniSTRATIVE LAw 48-49 (1994) (citing examples of deregulation during the Carter and Reagan administrations). 
state is still practically ubiquitous. ${ }^{254}$ The burdens of regulation are notorious to interested parties, in terms of both the sheer cost of agency action and the interference with permissible ranges of free choice. $^{255}$

This observation forms the basis for a deep objection to the applicability of the distributive exemption to state action. It might be argued that because the intervention of the modern state is so pervasive and burdensome, state action has become a threat by its very ubiquity. The argument here is not that the costs of governmental action outweigh the benefits. Instead, the claim is that the ubiquity of governmental action has altered the character of state intervention, such that it is no longer appropriate to conceptualize governmental intervention as a diversion for purposes of the distributive exemption. If so, deontological morality might require a government akin to the classic libertarian "night-watchman" state. ${ }^{256}$ That is, state intervention might still be justified under the distributive exemption in order to protect society from the anarchy threatened by the state of nature. Trying to do more, however, might transform the diversionary character of the state's intervention into an independent threat that is not justified under the distributive exemption. If this objection succeeds, governmental action must be neither pervasive nor frequent.

One response is simply to say that governmental intervention is permissible until the state's pervasiveness, as such, develops into a threat. This response is not particularly useful, however, because the property of pervasiveness lies on a continuum. No clear boundaries separate the state that is oppressive due to its pervasiveness from the nonoppressive, but still activist, state. Thus, instead of attempting to counter the libertarian objection directly, let us grant its premise. Take it as given that over a period of many years and gradual expansion, the state has evolved such that it, along with previously recog-

254 "Administrative agencies, after all, are so ubiquitous in American society that we take them utterly for granted-rather like VCRs, suburbs, and advertising. New ones are always being created, old ones seldom expire, and their permanence seems secure despite the Constitution's relative silence about them." Id. at 9.

${ }^{255}$ President Jimmy Carter, formerly a peanut farmer, once said, "It should not have taken 12 years and a hearing record of over 100,000 pages for the FDA to decide what percentage of peanuts there ought to be in peanut butter." President's News Conference of Mar. 25, 1979, 1 PUB. PAPERS 482, 484 (1979).

${ }^{236}$ See NOzICK, supra note 4, at 26-27 ("The night-watchman state of classical liberal theory [is] limited to the functions of protecting all its citizens against violence, theft, and fraud, and to the enforcement of contracts, and so on ...."); supra text accompanying notes 214-15 (quoting Nozick). 
nized threats (e.g., the unchecked passions of others), now constitutes a threat. What is the result?

The first thing to note is that because we are still working within the moral framework of deontology, the distributive exemption is still pertinent. The difference is that instead of drawing the analogy between the state and the passerby, we should draw the analogy between the state and the trolley. We, as citizens exercising control over our democratic state, ${ }^{257}$ now have the role analogous to the passerby in Thomson's example. ${ }^{258}$ As will be demonstrated below, this change has fewer implications than might be expected.

It might be thought obvious that minimizing state-caused harm requires scaling back government. Even if downsizing government resulted in less overall good, one might argue that the inevitability ${ }^{259}$ and lesser-harm ${ }^{260}$ requirements that are embedded in the distributive exemption, their deontological character not perturbed by consequentialist concerns, mandate this result. However, things are not so simple. There are at least two reasons why an essentially libertarian conclusion does not follow from the second-order application of the distributive exemption to the state.

First, the state is not the only threat facing society. Although the anarchy of the state of nature may not be lurking just around the corner, unfettered human passions are still a significant threat in the absence of the stabilizing influence of governmental action. The distributive exemption justifies governmental action to remedy those harms up to the point where the state is so pervasive that its ubiquity threatens harm. This limitation potentially still leaves significant room for an active state. As noted above, however, no clear boundary separates the pervasively oppressive state from the nonoppressive but active state. Thus, those who believe that indefensible ubiquity lies just beyond the night-watchman state bear the burden of demonstrating why this is so. In defending this claim, the libertarian must heed two points. First, traditional appeals to property rights and the like will not provide the libertarian with a sufficient defense, since the ar-

${ }^{257}$ A democratic state is not necessary for the application of the distributive exemption to the state. In a dictatorial government, the moral obligation would fall on the dictator instead of the citizens.

${ }_{253}$ Given the continuing direction citizens exercise over a democratic state, a more apt analogy may emerge if we see ourselves as trolley drivers instead of passers-by. Nothing interesting turns on this difference, however.

${ }^{259}$ See supra text accompanying note 179.

250 See supra text accompanying note 152. 
guments above already have established that the distributive exemption permits infringement of such rights. The only harm relevant at this point in the argument is the harm resulting from the ubiquity of the modern state. Second, in arguing that the more-than-minimal state constitutes a threat by its ubiquity, the libertarian must show more than that a powerful government may be threatening to a citizen who feels insignificant in comparison. Vague anxieties of this sort are not harms protected by stringent rights. It is important to remember that the version of rights defended here is not absolute. Thomson's Tradeoff Idea, followed here, allows rights to be infringed when doing so produces significantly much more good. ${ }^{261}$ The libertarian therefore must show that the harms caused by the pervasiveness of the ubiquitous state are not significantly outweighed by the benefits of the governmental action in question. Demonstrating that we have stringent rights against governmental ubiquity would satisfy this burden, but defending that claim would be no easy task. Because this first point depends, in part, on drawing a line about which no clear standard exists, I will not press further here.

The second reason that an essentially libertarian conclusion does not follow from the second-order application of the distributive exemption to the state is more fundamental. Because the state fills a special role in society, state action and the exercise of passion are interrelated and cannot properly be understood independently. ${ }^{262}$ In the case of an individual, "inaction" is not properly counted as action. ${ }^{263}$ But because the state is the only legitimate creator of certain types of social rules (i.e., legal rules), people act in reliance on both the existence and nonexistence of these rules. The special role of the state encompasses coordinating collective action by establishing the rules that define, in part, the parameters of permissible behavior. Therefore, the lack of state sanction against doing a particular thing legitimately may be relied on as a prima facie reason to think the

${ }^{261}$ See supra text accompanying notes 87-88.

${ }^{262}$ See CASS R. SUNSTEIN, THE PARTIAL CONSTITUTION 166-73 (1993) (discussing how governmentalallocations affect preferences); id. at 3 (noting that "the very categories of government 'action' and 'inaction' are given their content by the status quo").

${ }^{2}$ See H.L.A. HART \& TONYHONORÉ, CAUSATIONIN THE LAW 26-83, 29 (2d ed. 1985) (noting that "a cause is essentially something which interferes with or intervenes in the course of events which would normally take place"); see also MiCHAELS. MOORE, ACT AND CRIME 225-38 (1993) (discussing and defending the identity of actions and willed bodily movements). I am not adopting these causal theories as my own. I do claim, however, that any plausible account of causation will make judgments materially equivalent to the one in the text above about relevantlysimilar cases. 
thing socially permissible. ${ }^{264}$ Deregulation has causal impact. For example, the problems in the savings-and-loan industry in the 1980s are usually causally attributed to governmental deregulation. ${ }^{265}$ Failure to regulate also clearly has consequences. For instance, the future vitality of the Internet arguably depends in part on the degree to which the government fails to regulate its development. ${ }^{26}$ Thus, in the special case of the state, lack of intervention, and certainly deregulation, are actions for purposes of the distributive exemption. So although threats may be found in state action, threats also may exist in state inaction. $^{267}$ If scaling back the state causes more societal harm than good, the state is the proximate cause of the resulting harm.

Minimizing governmental harm is no simple matter. It involves complex calculations and the interweaving of policies of inaction with policies of civil, criminal, and regulatory action. However one thinks these processes ideally should work in detail, this conclusion comports well with broadly liberal ${ }^{263}$ notions of proper governmental action. The distributive exemption claims that the desirable role for government is to attempt to provide for the general welfare as consequentially calculated, while taking into account the cost of governmental intervention. Deontological principles of good standing have

${ }^{2+4}$ For instance, those opposing drug decriminalization often argue that this would lead to a significant rise in drug use. See Juan R. Torruella, One Judge's Attempt at a Rational Discussion of the So-Called War on Drugs, 6 B.U. PUB. INT. L.J. 1, 20-23 (discussing possible effects of legalization). These prima facie reasons may, of course, be overridden by other reasons, such as strong moral or cultural factors.

${ }^{265}$ See, e.g., Stephen K. Mayo, Housing Poligy: Changing the Structure, 31 FIN. \& DEV. 44,45 ("The $\$ 300$ billion cost to American taxpayers of the 'savings and loan scandal' provides graphic evidence of the cost of unchecked deregulation and poor oversight of housing finance institutions." ).

${ }_{266}$ Hence, the great public interest in whether the courts would uphold the Communications Decency Act. See ACLU v. Reno, 929 F. Supp. 824, 849 (E.D. Pa. 1996) (granting a preliminary injunction to prevent enforcement of the Act on the grounds that it is likely to be violative of First Amendment freedoms), affd, 117 S. Ct. 2329 (1997). In this particular case, the text's "failure to regulate" should be construed as "lack of success in regulating."

${ }^{267}$ This conclusion adds credibility to the notion that we may instructively understand the government as a trolley. For if any government action, as well as any government inaction, will result in costs causally attributable to the state, then harm is inevitable. This was one of the features essential to the Trolley Problem, triggering the distributive exemption. See supra text accompanying note 179.

${ }_{26 s}$ Conservatives who believe that the government does more harm than good by providing, for example, extensive welfare benefits, are classified here as "broadly liberal." The phrase excludes, however, principled libertarians and anarchists, as well as statists who desire governmental intervention for principled reasons, whatever the resulting social costs. 
thus explained why the state is permitted to do that which would be deontologically impermissible for individuals to do. In short, an exception to deontology has swallowed up the rule with respect to state action.

\section{CONCLUSION}

This Comment seeks to dissipate the tension Blackstone broached when he stated that the "eternal boundaries" provided by our "indelible rights" sometimes must be "modified" or "narrowed" by the "local or occasional necessities of the state." Rights, as trumps against the world, ostensibly ought not to be things that may be cast aside. Yet, it is intuitively obvious that the state justifiably acts in ways impermissible for individuals as it collects taxes, punishes wrongdoers, and the like. Others have offered explanations for why coercive state action is morally justified. This Comment adds another.

This Comment began by adopting deontology as a foundational theoretic assumption and briefly describing how deontology was to be understood herein. I then examined the characteristics of two leading theories of rights-Dworkin's theory of legal rights and Thomson's theory of moral rights. Although neither Dworkin nor Thomson is an absolutist with respect to rights, neither account explains why the state, but not individuals, may act in ways seemingly justifiable only on consequentialist grounds: that is, why the state may override the trumping effect of rights. In attempting to provide an answer to this question, I first noted that deontology does not exhaust moral discourse. The deontologist is forced to recognize that rights cannot capture everything of moral importance. I then provided several examples of distinctions recognized in the philosophical literature that delimit areas in which deontology does not apply, focusing in particular on the Trolley Problem and the distributive exemption from deontological norms that the Trolley Problem illustrates. The deontological exemption was examined fairly closely in order to enumerate the criteria that trigger the exemption and understand the principles that guide its application.

By applying the distributive exemption to the state, I accomplished two things. First, I was able to provide a new justification for the existence of the coercive state, both when premised on the traditional assumptions of social contractarians, and when premised on a

${ }^{269} 4$ BLACKSTONE, supra note 1 , at $* 2$. 
more realistic understanding of the modern state. Second, I was able to sketch the relationship between the constraints of rights and the demands of policy, justifying a state that provides for the general welfare without violating rights in a way objectionable to liberals.

Libertarians have argued that such a state violates deontological norms, that governmental intervention going beyond what is minimally necessary to preserve social order is not justified. Deontology does not require such a timid state and, moreover, finds desirable a state which promotes the general welfare to the fullest extent possible, even if in so doing it acts in ways deontologically objectionable for anyone other than one filling the government's unique role in society. More specifically, I argued that the government must consequentially justify its policy choices. The elegance of this particular rationale for the contours of permissible governmental action is that it remains a deontological justification at base. One of the worries of full-blown consequentialism is that it requires too much, that any putative right may be set aside if doing so would produce greater good. The justification offered here does not suffer that flaw. The distributive exemption does not permit that any one be sacrificed for the betterment of others; rather, it only permits a redistribution of inevitable harms, a diversion of an existing threatened harm to many such that it results in harm to fewer individuals.

The result of this application of the distributive exemption is a government that fundamentally seeks to promote to the fullest extent possible the welfare of all; a government that respects the rights of its citizens; and a government that realizes that its own intervention can have consequences counterproductive to the state's fundamental goal of general welfare that should be avoided for that reason. Such a state is a worthy totem, and accords with our most cherished principles molded through centuries of grappling with difficult legal and moral issues.

Deontological premises have justified a plausible and attractive version of the liberal state in which consequential justification predominates, but rights are not neglected. This conclusion should be both surprising and reassuring to the deontologist-surprising because deontology and consequentialism are typically understood to be in opposition, and reassuring because most people's intuitions that the state is permitted to reason consequentially are firmly entrenched. To the degree that deontology could not account for these intuitions, deontology would be that much less credible. 
